Virginia Commonwealth University

VCU Scholars Compass

2013

\title{
Hydration of the pyrimidine radical cation and stepwise solvation of protonated pyrimidine with water, methanol, and acetonitrile
}

\author{
Ahmed M. Hamid \\ Virginia Commonwealth University \\ Pramod Sharma \\ Virginia Commonwealth University \\ M. Samy El-Shall \\ Virginia Commonwealth University, mselshal@vcu.edu \\ See next page for additional authors
}

Follow this and additional works at: http://scholarscompass.vcu.edu/chem_pubs

Part of the Chemistry Commons

Hamid, A. M., Sharma, P., \& El-Shall, M. S., et al. Hydration of the pyrimidine radical cation and stepwise solvation of protonated pyrimidine with water, methanol, and acetonitrile. The Journal of Chemical Physics, 139, 084304 (2013). Copyright (C) 2013 AIP Publishing LLC.

\section{Downloaded from}

http://scholarscompass.vcu.edu/chem_pubs/63

This Article is brought to you for free and open access by the Dept. of Chemistry at VCU Scholars Compass. It has been accepted for inclusion in Chemistry Publications by an authorized administrator of VCU Scholars Compass. For more information, please contact libcompass@vcu.edu. 
Authors

Ahmed M. Hamid, Pramod Sharma, M. Samy El-Shall, Rifaat Hilal, Shaaban Elroby, Saadullah G. Aziz, and Abdulrahman O. Alyoubi 


\title{
Hydration of the pyrimidine radical cation and stepwise solvation of protonated pyrimidine with water, methanol, and acetonitrile
}

\author{
Ahmed M. Hamid, ${ }^{1}$ Pramod Sharma, ${ }^{1}$ M. Samy El-Shall, ${ }^{1, a)}$ Rifaat Hilal, ${ }^{2}$ \\ Shaaban Elroby, ${ }^{2}$ Saadullah G. Aziz, ${ }^{2}$ and Abdulrahman O. Alyoubi ${ }^{2}$ \\ ${ }^{1}$ Department of Chemistry, Virginia Commonwealth University, Richmond, Virginia 23284-2006, USA \\ ${ }^{2}$ Department of Chemistry, Faculty of Science King Abdulaziz University, Jeddah 21589, Saudi Arabia
}

(Received 1 July 2013; accepted 10 July 2013; published online 23 August 2013)

\begin{abstract}
Equilibrium thermochemical measurements using an ion mobility drift cell technique have been utilized to investigate the binding energies and entropy changes associated with the stepwise hydration of the biologically significant ions pyrimidine radical cation and protonated pyrimidine. The binding energy of the hydrated pyrimidine radical cation is weaker than that of the proton-bound dimer pyrimidine $\mathrm{H}^{+}\left(\mathrm{H}_{2} \mathrm{O}\right)$ consistent with the formation of a weak carbon-based $\mathrm{CH}^{\delta+} \ldots \mathrm{OH}_{2}$ hydrogen bond $(11.9 \mathrm{kcal} / \mathrm{mol})$ and a stronger $\mathrm{NH}^{+} \ldots \mathrm{OH}_{2}$ hydrogen bond $(15.6 \mathrm{kcal} / \mathrm{mol})$, respectively. Other proton-bound dimers such as pyrimidine $\mathrm{H}^{+}\left(\mathrm{CH}_{3} \mathrm{OH}\right)$ and pyrimidine $\mathrm{H}^{+}\left(\mathrm{CH}_{3} \mathrm{CN}\right)$ exhibit higher binding energies $(18.2 \mathrm{kcal} / \mathrm{mol}$ and $22.8 \mathrm{kcal} / \mathrm{mol}$, respectively) due to the higher proton affinities and dipole moments of acetonitrile and methanol as compared to water. The measured collisional cross sections of the proton-bound dimers provide experimental-based support for the DFT calculated structures at the M06-2x/6-311++G (d,p) level. The calculations show that the hydrated pyrimidine radical cation clusters form internally solvated structures in which the water molecules are bonded to the $\mathrm{C}_{4} \mathrm{~N}_{2} \mathrm{H}_{4}{ }^{\bullet+}$ ion by weak $\mathrm{CH}^{\delta+} \ldots \mathrm{OH}_{2}$ hydrogen bonds. The hydrated protonated pyrimidine clusters form externally solvated structures where the water molecules are bonded to each other and the ion is external to the water cluster. Dissociative proton transfer reactions $\mathrm{C}_{4} \mathrm{~N}_{2} \mathrm{H}_{4}{ }^{\bullet+}\left(\mathrm{H}_{2} \mathrm{O}\right)_{\mathrm{n}-1}+\mathrm{H}_{2} \mathrm{O}$ $\rightarrow \mathrm{C}_{4} \mathrm{~N}_{2} \mathrm{H}_{3}{ }^{\bullet}+\left(\mathrm{H}_{2} \mathrm{O}\right)_{n} \mathrm{H}^{+}$and $\mathrm{C}_{4} \mathrm{~N}_{2} \mathrm{H}_{5}{ }^{+}\left(\mathrm{H}_{2} \mathrm{O}\right)_{\mathrm{n}-1}+\mathrm{H}_{2} \mathrm{O} \rightarrow \mathrm{C}_{4} \mathrm{~N}_{2} \mathrm{H}_{4}+\left(\mathrm{H}_{2} \mathrm{O}\right)_{\mathrm{n}} \mathrm{H}^{+}$are observed for $\mathrm{n} \geq 4$ where the reactions become thermoneutral or exothermic. The absence of the dissociative proton transfer reaction within the $\mathrm{C}_{4} \mathrm{~N}_{2} \mathrm{H}_{5}{ }^{+}\left(\mathrm{CH}_{3} \mathrm{CN}\right)_{\mathrm{n}}$ clusters results from the inability of acetonitrile molecules to form extended hydrogen bonding structures such as those formed by water and methanol due to the presence of the methyl groups which block the extension of hydrogen bonding networks. (C) 2013 AIP Publishing LLC. [http://dx.doi.org/10.1063/1.4817327]
\end{abstract}

\section{INTRODUCTION}

Intermolecular forces, including hydrogen bonds and ion-molecule interactions, ${ }^{1-5}$ are important in many biological, chemical, and astrochemical processes such as the conformation and folding of proteins, base pair stacking in DNA, drug design, macromolecular assemblies, molecular recognition, clathrate hydrate formation, ices, and the formation of complex organics and ices in interstellar space. ${ }^{1-8}$

Ionic hydrogen bonds are strong intermolecular forces, often $10-30 \mathrm{kcal} / \mathrm{mol}$, which can form in ionizing environments between radical ions or protonated molecules and neutral molecules. ${ }^{1}$ Such bonds can form between stable organic molecular ions and polar solvent molecules such as water, methanol, and acetonitrile. ${ }^{1}$ For example, organic ions can interact with water molecules by either relatively weak carbon-based $\mathrm{CH}^{\delta+}$-O hydrogen bonds, such as in benzene radical cation, or via stronger hydrogen bonds, such as in protonated pyridine where the $\mathrm{NH}^{+}-\mathrm{O}$ hydrogen bonds are formed. ${ }^{9-11}$ Insight into the basic molecular interactions can be obtained from the energies and structures of the key species

\footnotetext{
${ }^{a)}$ Author to whom correspondence should be addressed. Electronic mail: mselshal@vcu.edu
}

involved in the stepwise association of polar molecules with organic ions. These data can be obtained experimentally by measuring binding energies and ion mobility of the cluster ions, and computationally by calculating the structures and binding energies of the hydrated and solvated organic ions. ${ }^{12-16}$

In recent papers we examined such interactions in the hydration of the organic ions: benzene $\left(\mathrm{C}_{6} \mathrm{H}_{6}{ }^{+}\right)$, cyclic $\mathrm{C}_{3} \mathrm{H}_{3}{ }^{+}$, acetylene $\left(\mathrm{C}_{2} \mathrm{H}_{2}{ }^{+} \cdot\right)$, acetylene dimer $\left(\mathrm{C}_{2} \mathrm{H}_{2}\right)_{2}{ }^{+}$, acetylene trimer $\left(\mathrm{C}_{2} \mathrm{H}_{2}\right)_{3}{ }^{+}$, phenyl acetylene $\left(\mathrm{C}_{8} \mathrm{H}_{6}{ }^{+}\right)$, pyridine $\left(\mathrm{C}_{5} \mathrm{H}_{5} \mathrm{~N}^{+\cdot}\right)$, 2-flouropyridine $\left(\mathrm{C}_{5} \mathrm{H}_{4} \mathrm{NF}^{+\cdot}\right)$, and protonated pyridine $\left(\mathrm{C}_{5} \mathrm{H}_{5} \mathrm{NH}^{+}\right)$using a combination of equilibrium thermochemical measurements, ion mobility, and DFT calculations. ${ }^{9-11,16-20}$ The hydration energies of these organic ions vary over an unexpected wide range from 8 to 18 $\mathrm{kcal} / \mathrm{mol}$ depending on the nature of the hydrogen bonding interaction. ${ }^{9-11,16-20}$ For example, benzene radical cation interacts with water molecules by relatively weak $\mathrm{CH}^{\delta+} \ldots \mathrm{O}$ hydrogen bonds resulting in stepwise hydration energies, $\Delta \mathrm{H}_{\mathrm{n}-1, \mathrm{n}}$, where $\mathrm{n}$ is the number of water molecules, that are nearly constant at $8.5 \pm 1 \mathrm{kcal} / \mathrm{mol}$ for $\mathrm{n}=1-6 .{ }^{9}{ }^{10}$ Dissociative proton transfer is observed in the $\mathrm{C}_{6} \mathrm{H}_{6}{ }^{+} \cdot\left(\mathrm{H}_{2} \mathrm{O}\right)_{n}$ clusters with $\mathrm{n} \geq 4$ resulting in the generation of protonated water clusters, $\mathrm{H}_{3} \mathrm{O}^{+}\left(\mathrm{H}_{2} \mathrm{O}\right)_{\mathrm{n}}$ with $\mathrm{n} \geq 3$ and the phenyl 
radical $\left(\mathrm{C}_{6} \mathrm{H}_{5} \cdot\right) .{ }^{10}$ Phenyl acetylene radical cation $\left(\mathrm{C}_{8} \mathrm{H}_{6}{ }^{+} \cdot\right)$ forms two kinds of $\mathrm{CH}^{\delta+} \ldots \mathrm{O}$ hydrogen bonds with water molecules through the interaction with the hydrogen atoms of the phenyl and acetylene groups. ${ }^{16}$ Hydration of the acetylene radical cation $\left(\mathrm{C}_{2} \mathrm{H}_{2}{ }^{+\cdot}\right)$ results in the formation of two covalent ions $\mathrm{C}_{2} \mathrm{H}_{3} \mathrm{O}^{+}$and $\mathrm{C}_{2} \mathrm{H}_{4} \mathrm{O}^{+}$. produced with an overall rate coefficient that increases with decreasing temperature. ${ }^{19}$ The reactivity, combined with energetics, suggests that the $\mathrm{C}_{2} \mathrm{H}_{4} \mathrm{O}^{+}$. adduct is vinyl alcohol $\left(\mathrm{H}_{2} \mathrm{C}=\mathrm{CHOH}^{+\cdot}\right)$, while the protonated ketene $\mathrm{CH}_{2} \mathrm{COH}^{+}$is most likely the $\mathrm{C}_{2} \mathrm{H}_{3} \mathrm{O}^{+}$ion observed. ${ }^{19}$ The measured hydration energy can confirm the covalent nature of the organic ions as in the case of the acetylene trimer ion $\left(\mathrm{C}_{2} \mathrm{H}_{2}\right)_{3}{ }^{+}$. where its sequential hydration energies with 1-6 water molecules are found to be identical to those of the benzene ion thus confirming the formation of benzene cations following the Electron Impact (EI) ionization of acetylene clusters. ${ }^{18,21}$ Similarly, the measured hydration energy combined with structural calculations of the acetylene dimer ion $\left(\mathrm{C}_{4} \mathrm{H}_{4}{ }^{+}\right.$.) confirms the formation of cyclobutadiene ${ }^{+}$. as the major isomer of the $\mathrm{C}_{4} \mathrm{H}_{4}{ }^{+}$. ions formed in EI ionized acetylene clusters. ${ }^{20}$ Interestingly, the hydration energy of the cyclic $\mathrm{C}_{3} \mathrm{H}_{3}{ }^{+}$ion $(11.7 \mathrm{kcal} / \mathrm{mol})$ is higher than those of the $\mathrm{C}_{6} \mathrm{H}_{6}{ }^{+\cdot}$ and $\mathrm{C}_{8} \mathrm{H}_{6}{ }^{+}$. ions reflecting the higher charge density on the $\mathrm{C}_{3} \mathrm{H}_{3}{ }^{+}$ion as compared to the larger radical cations $\mathrm{C}_{6} \mathrm{H}_{6}{ }^{+}$and $\mathrm{C}_{8} \mathrm{H}_{6}{ }^{+} .{ }^{17}$ The hydration energy can also identify the nature of the charge on the organic ion and distinguish between a conventional radical cation and a distonic ion. For example, the measured hydration energies of the pyridine and 2-F pyridine radical cations (15-16 $\mathrm{kcal} / \mathrm{mol}$ ) are consistent with distonic structures of these ions $\left({ }^{\bullet} \mathrm{C}_{5} \mathrm{H}_{4} \mathrm{NH}^{+}\right.$and ${ }^{\bullet} \mathrm{C}_{5} \mathrm{H}_{3} \mathrm{FNH}^{+}$, respectively) where the protonated nitrogen sites form stronger $\mathrm{NH}^{+} . \mathrm{OH}_{2}$ hydrogen bonds similar to protonated pyridines. ${ }^{11}$ The stepwise hydration of different organic ions can, thus, provide prototypical models for understanding structural and energy changes associated with hydration which could lead to a molecular level understanding of complicated condensed phase phenomena such as hydrophobic hydration and clathrate formation. ${ }^{4,5}$

Pyrimidine $\left(\mathrm{C}_{4} \mathrm{H}_{4} \mathrm{~N}_{2}\right)$ represents the major structural feature in three biological nucleobases: uracil (found in RNA only), thymine (found in DNA only), and cytosine (in both RNA and DNA), and it possesses two different proton acceptor sites: the ring $\pi$-cloud and the lone pairs of the heteroatoms. ${ }^{7}$ Therefore, pyrimidine solvation can be regarded as a prototype for the solvation of heterocyclic aromatic rings containing nitrogen heteroatoms. ${ }^{13,14}$ The structure of the pyrimidine-water neutral complex has been determined as a planar (or nearly planar) structure with a hydrogen bond between a nitrogen lone pair and the water hydrogen. ${ }^{22-25}$ Multiphoton ionization of the neutral pyrimidine (water) $)_{n}$ and pyrimidine (methanol) $)_{n}$ clusters produces the protonated cluster series $\mathrm{C}_{4} \mathrm{H}_{4} \mathrm{~N}_{2} \mathrm{H}^{+}\left(\mathrm{H}_{2} \mathrm{O}\right)_{n}$ and $\mathrm{C}_{4} \mathrm{H}_{4} \mathrm{~N}_{2} \mathrm{H}^{+}\left(\mathrm{CH}_{3} \mathrm{OH}\right)_{n}$, respectively, resulting from intracluster proton transfer reactions. ${ }^{26,27}$ However, the stepwise binding energies of these protonated pyrimidine clusters have not been experimentally determined. Similarly, the structures of these clusters have been calculated from $a b$ initio calculations, but no experimental based evidence for these structures has been reported.
In this paper, we provide a detailed experimental and theoretical study of the energetics and structures of the hydrated pyrimidine radical cation $\mathrm{C}_{4} \mathrm{H}_{4} \mathrm{~N}_{2}{ }^{\bullet+}\left(\mathrm{H}_{2} \mathrm{O}\right)_{n}$ with 1-4 water molecules, where two kinds of hydrogen bonds $\mathrm{CH}^{\delta+}-\mathrm{OH}_{2}$ or $\mathrm{N}^{\delta+}-\mathrm{H}_{2} \mathrm{O}$ can be formed. For comparison, we also study the hydration of protonated pyrimidine $\left(\mathrm{C}_{4} \mathrm{H}_{4} \mathrm{~N}_{2}\right) \mathrm{H}^{+}\left(\mathrm{H}_{2} \mathrm{O}\right)_{\mathrm{n}}$ with $\mathrm{n}=1-3$ where stronger binding may occur through the proton-bound hetero dimer $\mathrm{C}_{4} \mathrm{H}_{4} \mathrm{~N}_{2} \mathrm{H}^{+} \mathrm{H}_{2} \mathrm{O}$. Furthermore, we compare the energetics and structures of the hydrated protonated pyrimidine with those involving methanol and acetonitrile $\left[\mathrm{C}_{4} \mathrm{H}_{4} \mathrm{~N}_{2} \mathrm{H}^{+}\left(\mathrm{CH}_{3} \mathrm{OH}\right)_{\mathrm{n}}\right.$ and $\mathrm{C}_{4} \mathrm{H}_{4} \mathrm{~N}_{2} \mathrm{H}^{+}\left(\mathrm{CH}_{3} \mathrm{CN}\right)_{\mathrm{n}}$, respectively] where the effect of the solvent polarity can be examined. To obtain energetics data, we use the drift tube thermochemical measurements, and for structural determination we use ion mobility measurements coupled with DFT structural calculations. The results provide new insights into the factors that determine the structures and energetics of the clusters of polar molecules with $\mathrm{N}$-containing heterocyclic organic ions.

\section{A. Experimental}

The thermochemical and ion mobility experiments were performed using the VCU mass-selected ion mobility spectrometer. The details of the instrument can be found in several publications, ${ }^{16-20}$ and only a brief description of the experimental procedure is given here (see Fig. S1, supplementary material). ${ }^{28}$

In the experiment, $\sim 0.5 \%-2 \%$ pyrimidine vapor (Aldrich, 99\% purity) seeded in 3-4 atm of the carrier gas, helium or $10 \%$ hydrogen in helium, is expanded through a pulsed conical nozzle (500 $\mu \mathrm{m}$ diameter) in pulses of 200 $300 \mu$ s duration at repetition rates of $50-100 \mathrm{~Hz}$. The neutral molecular beam is ionized by an axial electron-impact ionizer using $50-70 \mathrm{eV}$ electron energy. The pyrimidine ${ }^{+}$or the $\mathrm{H}^{+}$pyrimidine ions are mass-selected via the first quadrupole mass-filter. The ion beam is injected into the drift cell in $30-50-\mu$ s-wide packets using injection energies of 10-13 $\mathrm{eV}$, (laboratory frame) which are the minimum energies (depending on the pressure in the drift cell) to introduce the injected ions against the counter flow of the gas escaping from the cell. The drift cell contains the reactant water vapor, alone or in a mixture with helium buffer gas in the thermochemical measurements while it contains helium only in the mobility measurements. Most of the ion thermalization occurs outside the cell entrance by collisions with the solvent molecules and $\mathrm{He}$ atoms escaping from the cell entrance orifice. At a cell pressure of 0.2 Torr, the number of collisions that the pyrimidine ion encounters within the $1.5 \mathrm{~ms}$ residence time inside the cell is about $10^{4}$ collisions, which is sufficient to ensure efficient thermalization of the ions. The temperature of the drift cell can be controlled to better than $\pm 1 \mathrm{~K}$ using four temperature controllers. Liquid nitrogen flowing through solenoid valves is used to cool down the drift cell. The reaction products can be identified by scanning a second quadrupole mass filter located coaxially after the drift cell. The arrival time distributions (ATDs) are collected by monitoring the intensity of each ion as a function of time. The reaction time can be varied by varying the drift voltage. 
As an example, the ATDs of the reactant $\left(\mathrm{C}_{4} \mathrm{~N}_{2} \mathrm{H}_{4}{ }^{\bullet+}\right)\left(\mathrm{H}_{2} \mathrm{O}\right)_{\mathrm{n}-1}$ and product $\left(\mathrm{C}_{4} \mathrm{~N}_{2} \mathrm{H}_{4}{ }^{\bullet+}\right)\left(\mathrm{H}_{2} \mathrm{O}\right)_{\mathrm{n}}$ ions are measured as a function of the drift voltage across the cell. The ion intensity ratio, $\left(\mathrm{C}_{4} \mathrm{~N}_{2} \mathrm{H}_{4}{ }^{\bullet+}\right)\left(\mathrm{H}_{2} \mathrm{O}\right)_{\mathrm{n}} /\left(\mathrm{C}_{4} \mathrm{~N}_{2} \mathrm{H}_{4}{ }^{\bullet+}\right)\left(\mathrm{H}_{2} \mathrm{O}\right)_{\mathrm{n}-1}, \quad$ is measured from the integrated peak areas of the ATDs as a function of decreasing cell drift field corresponding to increasing reaction times, and equilibrium is achieved when a constant ratio is obtained. Under these conditions, the equilibrium constant is then obtained using Eq. (1),

$$
\mathrm{K}_{\mathrm{eq}}=\mathrm{I}\left[\mathrm{C}_{4} \mathrm{~N}_{2} \mathrm{H}_{4}^{\bullet+}\left(\mathrm{H}_{2} \mathrm{O}\right)_{\mathrm{n}}\right] / \mathrm{I}\left[\mathrm{C}_{4} \mathrm{~N}_{2} \mathrm{H}_{4}^{\bullet+}\left(\mathrm{H}_{2} \mathrm{O}\right)_{\mathrm{n}-1}\right] \mathrm{P}\left(\mathrm{H}_{2} \mathrm{O}\right) \text {, }
$$

where $\mathrm{I}$ is the intensity of the ion peak taken from the integrated ATD. The equilibrium constants measured as a function of temperature yield $\Delta \mathrm{H}^{\circ}$ and $\Delta \mathrm{S}^{\circ}$ from the slopes and intercepts, respectively, of the van't Hoff plots. All of the results are replicated three or more times.

\section{B. Theoretical}

DFT calculations of the lowest energy structures of the $\left(\mathrm{C}_{4} \mathrm{~N}_{2} \mathrm{H}_{4}{ }^{\bullet+}\right)\left(\mathrm{H}_{2} \mathrm{O}\right)_{\mathrm{n}}$ and the $\mathrm{C}_{4} \mathrm{~N}_{2} \mathrm{H}_{5}{ }^{+}(\mathrm{X})_{\mathrm{n}}\left(\mathrm{X}=\mathrm{H}_{2} \mathrm{O}\right.$, $\mathrm{CH}_{3} \mathrm{OH}, \mathrm{CH}_{3} \mathrm{CN}$ ) clusters were carried out at the M06$2 X / 6-311++G(d, p)$ level using the GAUSSIAN 09 suite of programs. ${ }^{29}$ Frequency calculations have been performed for all the optimized geometries at the same level of theory to obtain the zero point vibrational energy (ZPVE) and to verify the absence of any imaginary frequencies. The calculated binding energies (with respect to pyrimidine ${ }^{\bullet+}\left(\mathrm{H}_{2} \mathrm{O}\right)_{n-1}+\mathrm{H}_{2} \mathrm{O}$ or pyrimidine $\left.\mathrm{H}^{+}(\mathrm{X})_{\mathrm{n}-1}+\mathrm{X}\right)$ were corrected for BSSE using the scheme of Boys and Bernardi as described in the Gaussian program. ${ }^{29}$ The ion mobility and collision cross sections were calculated by the trajectory method using Mobcal program which employs a potential composed of Lennard-Jones and ion-induced dipole interactions. ${ }^{30}$

\section{RESULTS AND DISCUSSION}

\section{A. Stepwise hydration of the pyrimidine radical cation and protonated pyrimidine}

Figures 1(a) and 1(b) display the mass spectra obtained following the injection of the pyrimidine radical cation and protonated pyrimidine, respectively, into the drift cell containing helium carrier gas or He-water mixtures at various pressures and temperatures as indicated in the figures.

In the absence of water in the drift cell, only the mass-selected pyrimidine radical cation is observed as shown in Fig. 1(a). In the presence of water, both the $\left(\mathrm{C}_{4} \mathrm{~N}_{2} \mathrm{H}_{4}{ }^{-+}\right)\left(\mathrm{H}_{2} \mathrm{O}\right)_{\mathrm{n}}$ with $\mathrm{n}=1-5$ and the protonated water series $\mathrm{H}^{+}\left(\mathrm{H}_{2} \mathrm{O}\right)_{n}$ with $\mathrm{n}=4-9$ are observed. They consistently shift towards higher $\mathrm{n}$ as the temperature of the drift cell decreases. For example, at $238 \mathrm{~K}(235 \mathrm{~K}$ is the lowest attainable temperature under our experimental conditions before water freezes out in the drift cell) the observed ions are $\left(\mathrm{C}_{4} \mathrm{~N}_{2} \mathrm{H}_{4}{ }^{\bullet+}\right)\left(\mathrm{H}_{2} \mathrm{O}\right)_{n}$ with $\mathrm{n}=2-5$ and $\mathrm{H}^{+}\left(\mathrm{H}_{2} \mathrm{O}\right)_{\mathrm{n}}$ with $\mathrm{n}=5-9$ as shown in Fig. 1(a). Similar observations are obtained by injecting the protonated pyrimidine into the drift cell
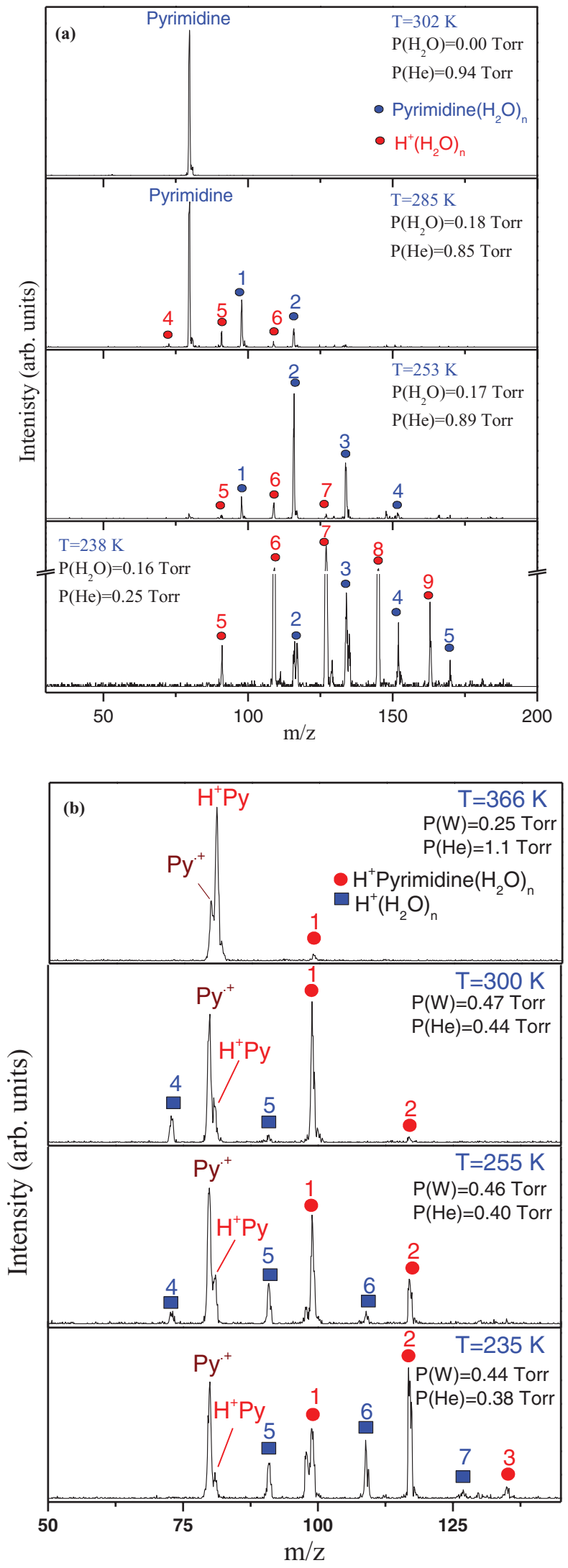

FIG. 1. (a) Mass spectra resulting from the injection of mass-selected pyrimidine radical cation into a helium $(\mathrm{He})$-water $(\mathrm{W})$ vapor mixture at different temperatures using $12.7 \mathrm{eV}$ injection energy (laboratory frame) and $2.5 \mathrm{~V} / \mathrm{cm}$ drift field. (b) Mass spectra resulting from the injection of mass-selected protonated pyrimidine $\left(\mathrm{H}^{+} \mathrm{Py}\right)$ into a helium $(\mathrm{He})$-water $(\mathrm{W})$ vapor mixture at different temperatures using $13.9 \mathrm{eV}$ injection energy (laboratory frame) and $2.2 \mathrm{~V} / \mathrm{cm}$ drift field. 
containing He-water mixtures as shown in Fig. 1(b). However, in this case the protonated clusters $\left(\mathrm{C}_{4} \mathrm{~N}_{2} \mathrm{H}_{5}{ }^{+}\right)\left(\mathrm{H}_{2} \mathrm{O}\right)_{\mathrm{n}}$ can be observed at higher temperatures as shown in Fig. 1(b) at $366 \mathrm{~K}$ and $300 \mathrm{~K}$ for the $\mathrm{C}_{4} \mathrm{~N}_{2} \mathrm{H}_{5}{ }^{+}\left(\mathrm{H}_{2} \mathrm{O}\right)$ and the $\left(\mathrm{C}_{4} \mathrm{~N}_{2} \mathrm{H}_{5}{ }^{+}\right)\left(\mathrm{H}_{2} \mathrm{O}\right)_{2}$ clusters, respectively. This indicates higher hydration energies for the protonated pyrimidine as compared to the pyrimidine radical cation.

The mass spectra displayed in Figs. 1(a) and 1(b) show the presence of protonated water clusters $\mathrm{H}^{+}\left(\mathrm{H}_{2} \mathrm{O}\right)_{n}$ with $\mathrm{n} \geq 4$. The formation of these ions is attributed to the dissociative proton transfer reactions shown in Reactions (2) and (3) below, similar to those previously observed in the hydration of benzene and phenylacetylene radical cations, ${ }^{9,10,16}$

$$
\left[\mathrm{C}_{4} \mathrm{H}_{4} \mathrm{~N}_{2}\left(\mathrm{H}_{2} \mathrm{O}\right)_{\mathrm{n}-1}\right]+\mathrm{H}_{2} \mathrm{O} \rightarrow \mathrm{C}_{4} \mathrm{H}_{3} \mathrm{~N}_{2}+\left[\mathrm{H}^{+}\left(\mathrm{H}_{2} \mathrm{O}\right)_{\mathrm{n}}\right] ; \mathrm{n} \geq 4 \text {, }
$$

$$
\begin{aligned}
& {\left[\mathrm{H}^{+} \mathrm{C}_{4} \mathrm{H}_{4} \mathrm{~N}_{2}\left(\mathrm{H}_{2} \mathrm{O}\right)_{\mathrm{n}-1}\right]+\mathrm{H}_{2} \mathrm{O}} \\
& \quad \rightarrow \mathrm{C}_{4} \mathrm{H}_{4} \mathrm{~N}_{2}+\left[\mathrm{H}^{+}\left(\mathrm{H}_{2} \mathrm{O}\right)_{\mathrm{n}}\right] ; \mathrm{n} \geq 4 .
\end{aligned}
$$

The proton transfer reactions (2) and (3) exhibit a critical size $(n \geq 4)$ where these reactions become exothermic. This can be rationalized by the proton affinity (PA) of the water subcluster needed to extract the proton from the pyrimidine radical cation (Reaction (2)) or from the protonated pyrimidine (Reaction (3)). The observation of $n \geq 4$ for both reactions indicates that the PA of the water tetramer $(n=4)$ must be higher than that of the $\mathrm{C}_{4} \mathrm{~N}_{2} \mathrm{H}_{3} \cdot$ radical (Reaction (2)) and also higher than that of the pyrimidine molecule (Reaction (3)). The PA of $\left(\mathrm{H}_{2} \mathrm{O}\right)_{4}$ can be estimated as $215 \mathrm{kcal} / \mathrm{mol}$ which is indeed higher than the PA of the pyrimidine molecule $(212 \mathrm{kcal} / \mathrm{mol}) .{ }^{10,31}$ This also indicates that the PA of the $\mathrm{C}_{4} \mathrm{~N}_{2} \mathrm{H}_{3}{ }^{\bullet}$ radical can be estimated as $<215 \mathrm{kcal} / \mathrm{mol}$. The observed proton transfer reactions generating the $\mathrm{H}^{+}\left(\mathrm{H}_{2} \mathrm{O}\right)_{\text {n }}$ ions with $\mathrm{n} \geq 4$ reflect the stability of the $\mathrm{H}_{3} \mathrm{O}^{+}$ion and its preferential solvation by three water molecules to form the closed shell solvated hydronium ion $\mathrm{H}_{3} \mathrm{O}^{+}\left(\mathrm{H}_{2} \mathrm{O}\right)_{3}$ cluster. ${ }^{1}$

Under the experimental conditions listed in Figs. 1(a) and 1(b), equilibrium could be established as indicated by the identical ATDs of the reactant and product ions. If the $\left(\mathrm{C}_{4} \mathrm{~N}_{2} \mathrm{H}_{4}{ }^{\bullet+}\right)\left(\mathrm{H}_{2} \mathrm{O}\right)_{n-1}$ and $\left(\mathrm{C}_{4} \mathrm{~N}_{2} \mathrm{H}_{4}{ }^{\bullet+}\right)\left(\mathrm{H}_{2} \mathrm{O}\right)_{n}$ ions are in equilibrium, their ATDs must be identical. This is evident from the ATDs of the $\left(\mathrm{C}_{4} \mathrm{~N}_{2} \mathrm{H}_{4}{ }^{\bullet+}\right)\left(\mathrm{H}_{2} \mathrm{O}\right)_{\mathrm{n}}$ ions with $\mathrm{n}=1-5$ and the $\left(\mathrm{C}_{4} \mathrm{~N}_{2} \mathrm{H}_{5}{ }^{+}\right)\left(\mathrm{H}_{2} \mathrm{O}\right)_{\mathrm{n}}$ ions with $\mathrm{n}=0-3$, as shown in Figs. S2 and S3, respectively (supplementary material).$^{28}$ The equilibrium constants for the stepwise hydration of the $\mathrm{C}_{4} \mathrm{~N}_{2} \mathrm{H}_{4}{ }^{\bullet+}$ and $\mathrm{C}_{4} \mathrm{~N}_{2} \mathrm{H}_{5}{ }^{+}$ions with 1-4 and 1-3 water molecules, respectively, are measured at different temperatures and the resulting van't Hoff plots are shown in Figs. 2(a) and 2(b), respectively. $\Delta \mathrm{H}^{\circ}$ and $\Delta \mathrm{S}^{\circ}$ values for each hydration step $(\mathrm{n}-1 \rightarrow \mathrm{n})$ are obtained from the slope and the intercept, respectively, of the corresponding van't Hoff plot. The measured values are duplicated at least three times for each equilibrium step and the average values are reported in Table I.

The results shown in Table I indicate that the binding energies of the pyrimidine ${ }^{\bullet+}\left(\mathrm{H}_{2} \mathrm{O}\right)_{n}$ clusters are weaker than those of the pyrimidine $\mathrm{H}^{+}\left(\mathrm{H}_{2} \mathrm{O}\right)_{n}$ clusters. In both series,
TABLE I. Measured thermochemistry $\left(\Delta \mathrm{H}_{n-1, n}^{\circ}\right.$ and $\left.\Delta \mathrm{S}_{\mathrm{n}-1, \mathrm{n}}^{\circ}\right)$ of the for-

\begin{tabular}{|c|c|c|c|c|c|c|}
\hline \multirow[b]{2}{*}{$\mathrm{n}$} & \multicolumn{3}{|c|}{ Pyrimidine ${ }^{+}$} & \multicolumn{3}{|c|}{ Protonated pyrimidine } \\
\hline & $-\Delta \mathrm{H}^{\mathrm{o} a}$ & $-\Delta S^{o b}$ & $\mathrm{BE}^{\mathrm{c}}$ & $-\Delta \mathrm{H}^{\mathrm{o} a}$ & $-\Delta S^{o b}$ & $\mathrm{BE}^{\mathrm{c}}$ \\
\hline 1 & 11.9 & 23.6 & $13.5(10.8)$ & 16.7 & 38.6 & $19.7(16.9)$ \\
\hline 2 & 10.4 & 18.8 & $13.4(10.3)$ & 12.7 & 35.6 & $15.0(12.9)$ \\
\hline 3 & 9.0 & 19.5 & $11.5(9.5)$ & 11.0 & 34.9 & 13.2 (11.6) \\
\hline 4 & 7.9 & 17.6 & $11.4(8.9)$ & & & \\
\hline
\end{tabular}
mation of pyrimidine ${ }^{+}\left(\mathrm{H}_{2} \mathrm{O}\right)_{n}$ and $\mathrm{H}^{+}$pyrimidine $\left(\mathrm{H}_{2} \mathrm{O}\right)_{n}$ clusters; with $\mathrm{n}=1-4$ and $\mathrm{n}=1-3$, respectively.

${ }^{\mathrm{a}} \Delta \mathrm{H}^{\circ} \mathrm{n}-1, \mathrm{n}$ units are $\mathrm{kcal} / \mathrm{mol}$.

${ }^{\mathrm{b}} \Delta \mathrm{S}^{\circ}{ }_{\mathrm{n}-1, \mathrm{n}}$ units are $\mathrm{cal} / \mathrm{molK}$.

${ }^{\mathrm{c}}$ Binding energy calculated at the M06-2X/6-311++G(d,p) level (with ZPE and BSSE corrections included).

the binding energies $-\Delta \mathrm{H}^{\mathrm{o}}{ }_{\mathrm{n}-1, \mathrm{n}}$ decrease with increasing $\mathrm{n}$ and, in the case protonated pyrimidine, approach the limiting macroscopic value of $10.5 \mathrm{kcal} / \mathrm{mol}$ condensation energy of water. ${ }^{1}$ This follows the usual trend in systems with conventional ionic hydrogen bonds. ${ }^{1}$
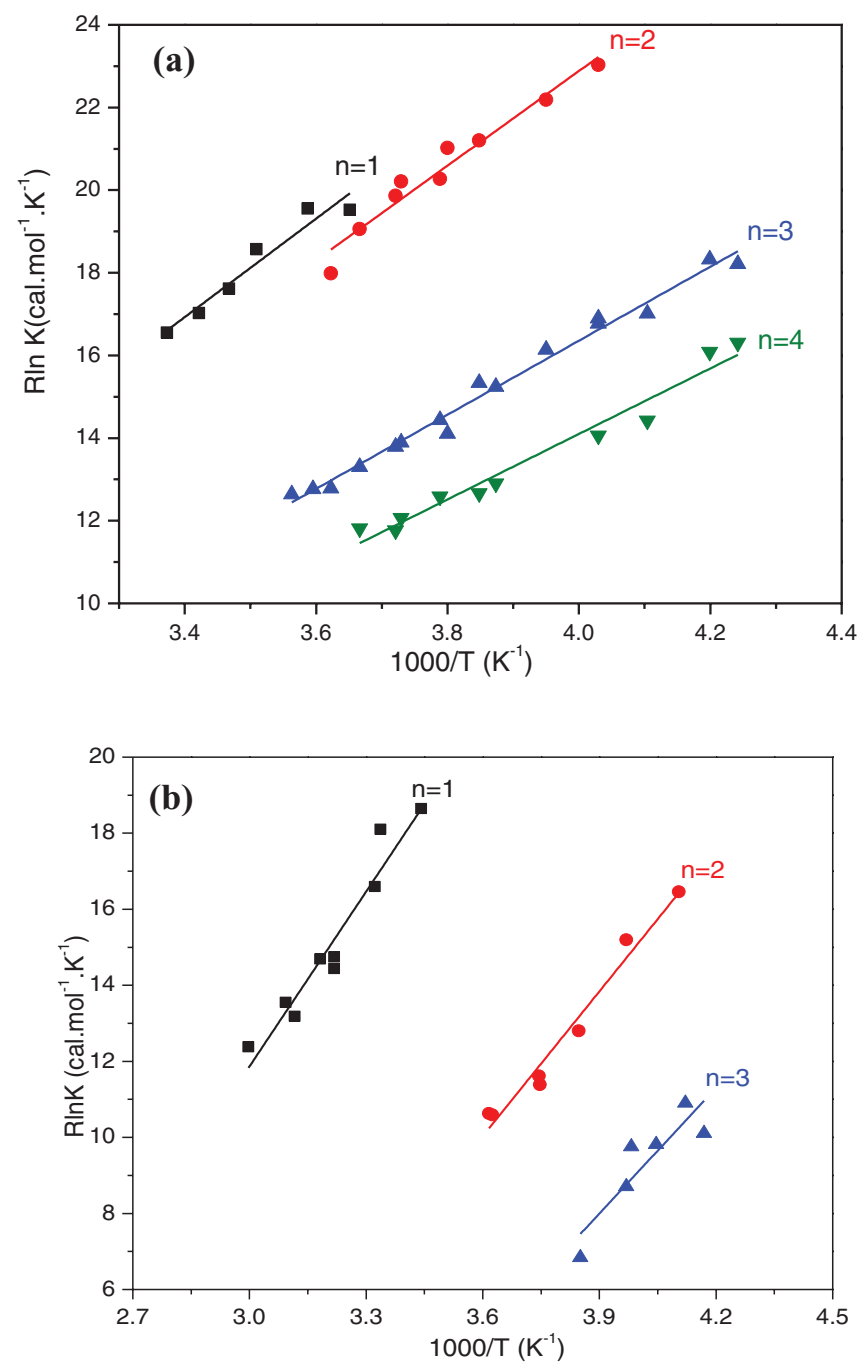

FIG. 2. Van't Hoff plots of the temperature dependence of the equilibrium constant of the stepwise hydration of (a) the pyrimidine radical cation and formation of pyrimidine ${ }^{+} \cdot\left(\mathrm{H}_{2} \mathrm{O}\right)_{\mathrm{n}}$ with $\mathrm{n}=1-4$, and (b) protonated pyrimidine and formation of $\mathrm{H}^{+}$pyrimidine $\left(\mathrm{H}_{2} \mathrm{O}\right)_{n}$ with $\mathrm{n}=1-3$. 
In relation to these data, we note that the $\mathrm{C}-\mathrm{H}$ hydrogens of the conventional pyrimidine radical cation $\left(\mathrm{C}_{5} \mathrm{H}_{4} \mathrm{~N}_{2}{ }^{\bullet+}\right)$ can only form carbon-based $\mathrm{CH}^{\delta+} . \mathrm{OH}_{2}$ bonds to water, similar to those formed by the benzene ${ }^{\bullet+}$ ion. ${ }^{9}{ }^{10}$ Such hydrogen bonds are typically weak, and the measured values in Table I are consistent with the 8-12 $\mathrm{kcal} \mathrm{mol}^{-1}$ observed in the hydration of benzene and phenylacetylene radical cations. ${ }^{9}, 10,16$ In fact, DFT calculations below also show that the hydrogen bond strength of the conventional pyrimidine ${ }^{\bullet+}$ ion to water is $10.8 \mathrm{kcal} / \mathrm{mol}$, in good agreement with the measured value of $11.9 \mathrm{kcal} / \mathrm{mol}$. In contrast, protonated pyrimidine forms a stronger $\mathrm{NH}^{+} . . \mathrm{OH}_{2}$ bond of $16.7 \mathrm{kcal} / \mathrm{mol} \mathrm{simi-}$ lar to the calculated value of $16.9 \mathrm{kcal} / \mathrm{mol}$ as shown in Table I. This situation is different from the hydration of the pyridine ions, where the measured binding energies of the pyridine ${ }^{\bullet+}\left(\mathrm{H}_{2} \mathrm{O}\right)_{n}$ clusters were similar to those of the protonated pyridine-water clusters, $\left(\mathrm{C}_{5} \mathrm{H}_{5} \mathrm{NH}^{+}\right)\left(\mathrm{H}_{2} \mathrm{O}\right)_{\mathrm{n}}$, that involve $\mathrm{NH}^{+} . . \mathrm{OH}_{2}$ bonds, and different from those of the hydrated benzene radical cation. These relations indicated that the hydrated pyridine ${ }^{\bullet+}$ ions have the distonic ${ }^{\circ} \mathrm{C}_{5} \mathrm{H}_{4} \mathrm{NH}^{+}$ structures that can form $\mathrm{NH}^{+} \ldots \mathrm{OH}_{2}$ bonds. ${ }^{11}$ Based on these comparisons, it can be concluded that the hydrated pyrimidine ions observed in the present work have the conventional radical cation structures similar to the hydrated benzene cation that forms $\mathrm{CH}^{\delta+} . . \mathrm{OH}_{2}$ bonds with water molecules. This could imply that the barrier for the rearrangement of the hydrated conventional pyrimidine radical cation to the distonic structure is higher than the corresponding barrier in the case of hydrated pyridine cation.

The gas phase hydration energy of protonated pyrimidine measured in this work $(16.7 \mathrm{kcal} / \mathrm{mol})$ is consistent with the hydration energies of other aromatic ions recently measured using energy-resolved collision-induced dissociation (CID). ${ }^{12}$ For example, the CID hydration energies of protonated aniline, acetophenone, and phenol were measured as 14.4, 15.6, and $17.5 \mathrm{kcal} / \mathrm{mol}$, respectively. The hydration energy of protonated pyrimidine is higher than that of aniline and slightly lower than that of phenol. The measured hydration energies appear to correlate well with the proton affinity of the aromatic molecules as discussed in Ref. 12.

\section{B. Calculated structures of the hydrated pyrimidine radical cation and protonated pyrimidine}

The calculated structures of the lowest energy isomers of the hydrated pyrimidine radical cation $\left(\mathrm{C}_{4} \mathrm{~N}_{2} \mathrm{H}_{4}{ }^{\bullet+}\right)\left(\mathrm{H}_{2} \mathrm{O}\right)_{n}$ with $\mathrm{n}=1-4$ are shown in Figs. 3 and 4. The lowest energy isomer of the monohydrated ion (PW1-a) has a bifurcated structure with $\mathrm{H}_{2} \mathrm{O}$ bonding to two $\mathrm{CH}$ hydrogens with relatively larger distances (2.4 $\AA$ and $2.2 \AA$ ) than typical H-bonds as shown in Fig. 3(a). This structure is similar to that found for the benzene ${ }^{\bullet+}\left(\mathrm{H}_{2} \mathrm{O}\right)$ complex. ${ }^{10}$ Other isomers PW1-b and PW1-c are slightly higher in energy and involve direct $\mathrm{CH}^{\delta+} . . \mathrm{OH}_{2}$ bonds of $1.9-2.0 \AA$ depending on the charge density on the $\mathrm{H}$ atoms of the pyrimidine cation.

The addition of the second water molecule forms both internally solvated structures (PW2-a and PW2-b in Fig. 3) in which both water molecules are bonded to the $\mathrm{C}_{4} \mathrm{~N}_{2} \mathrm{H}_{4}{ }^{\bullet+}$ ion, which is therefore "inside" the solvent, and an externally sol-

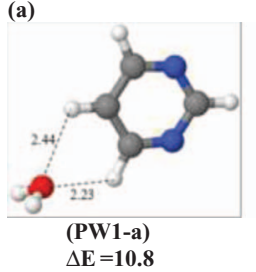

(b)

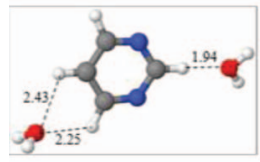

(PW2-a)

$\Delta \mathrm{E}=\mathbf{1 0 . 3}$

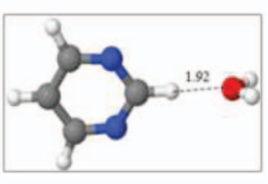

(PW1-b)

$\Delta \mathbf{E}=9.8$

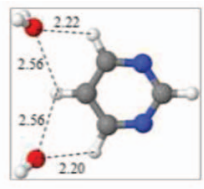

(PW2-b)

$\Delta \mathbf{E}=\mathbf{1 0 . 2}$
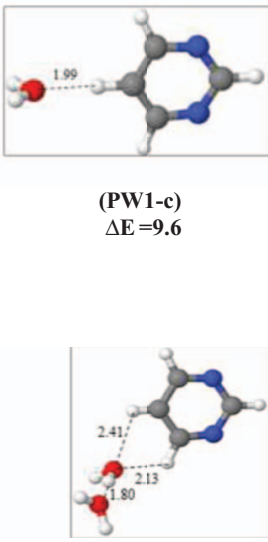

(PW2-c) $\Delta \mathrm{E}=\mathbf{1 0 . 1}$
FIG. 3. Structures of (a) pyrimidine ${ }^{+}\left(\mathrm{H}_{2} \mathrm{O}\right)$ and (b) pyrimidine ${ }^{+}\left(\mathrm{H}_{2} \mathrm{O}\right)_{2}$ calculated by DFT at the M06-2x/6-311++G (d,p) level. Binding energies $(\boldsymbol{\Delta E})$ are corrected for zero-point energies (ZPE) and basis-set super position errors (BSSE). Energies are in $\mathrm{kcal} / \mathrm{mol}$. Distances are in Angstrom.

vated structure (PW2-c in Fig. 3) where the water molecules are bonded to each other and the ion is external to this solvent cluster. Both types of structures have similar binding energies. The hydrogen bond of $1.8 \AA$ between the two water molecules in isomer PW2-c is shorter than that between the first water molecule and the $\mathrm{CH}$ of the pyrimidine ion (1.92 $\AA$ in PW1-b) reflecting the stronger interaction among the water molecules.

The lowest energy isomers of the $\mathrm{C}_{4} \mathrm{~N}_{2} \mathrm{H}_{4}{ }^{\bullet+}\left(\mathrm{H}_{2} \mathrm{O}\right)_{3}$ cluster also show both internally solvated (PW3-a) and externally solvated (PW3-b) structures with similar binding energies. Hydrogen bonding between three $\mathrm{H}_{2} \mathrm{O}$ molecules attached to the pyrimidine cation forms a cyclic structure (PW3-b) which apparently further stabilizes the cluster and increases the interaction with the cation as evident from the short
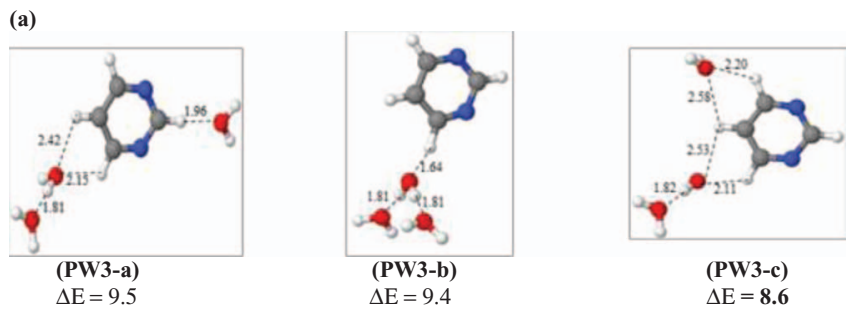

(b)

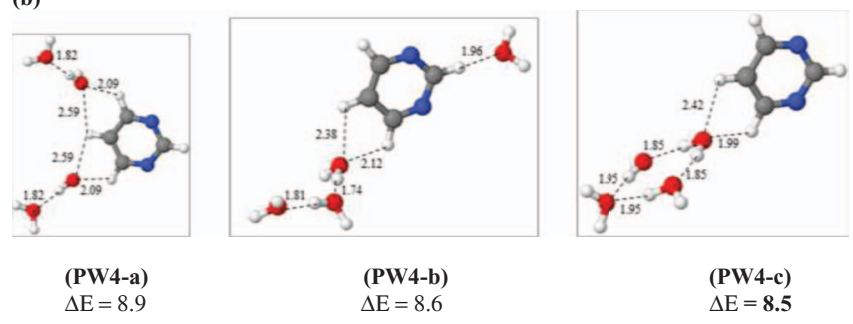

FIG. 4. Structures of (a) pyrimidine ${ }^{+}\left(\mathrm{H}_{2} \mathrm{O}\right)_{3}$ and (b) pyrimidine ${ }^{+}\left(\mathrm{H}_{2} \mathrm{O}\right)_{4}$ calculated by DFT at the M06-2x/6-311++G (d,p) level. Binding energies $(\boldsymbol{\Delta E})$ are corrected for zero-point energies (ZPE) and basis-set super position errors (BSSE). Energies are in $\mathrm{kcal} / \mathrm{mol}$. Distances are in Angstrom. 


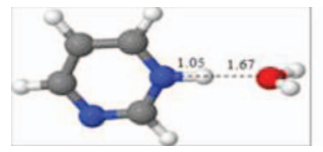

(PH ${ }^{+} \mathbf{W 1}$

$\Delta \mathbf{E}=16.9$

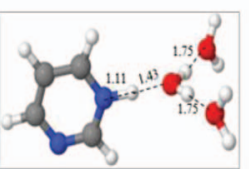

(PH ${ }^{+} \mathbf{W}$-a) $\Delta \mathbf{E}=11.9$

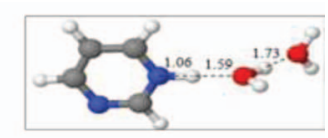

$\left(\mathbf{P H}^{+} \mathbf{W} 2\right)$
FIG. 5. Structures of $\mathrm{H}^{+}$pyrimidine $\left(\mathrm{H}_{2} \mathrm{O}\right)_{n}$ clusters with $\mathrm{n}=1-3$ calculated by DFT at the M06-2x/6-311++G (d,p) level. Binding energies $(\Delta \mathrm{E})$ are corrected for zero-point energies (ZPE) and basis-set super position errors (BSSE). Energies are in $\mathrm{kcal} / \mathrm{mol}$. Distances are in Angstrom.

$\mathrm{CH}^{\delta+} \ldots \mathrm{OH}_{2}$ hydrogen bond (1.6 $\AA$ ) in isomer PW3-b. The same trend continues to the $\mathrm{C}_{4} \mathrm{~N}_{2} \mathrm{H}_{4}{ }^{\bullet+}\left(\mathrm{H}_{2} \mathrm{O}\right)_{4}$ cluster where the largest binding energy is provided by isomer PW4-a where two water dimers form bifurcated bonds with the pyrimidine ion and represent an optimization between the internally and externally solvated structural motifs.

With respect to the observed deprotonation reaction (2), isomer PW4-c in Fig. 4 may be relevant. This isomer has a nearly similar binding energy $(8.5 \mathrm{kcal} / \mathrm{mol})$ to the measured value of $7.9 \mathrm{kcal} / \mathrm{mol}$, and it has the four water molecules bonded together in a common cyclic tetramer which allows pulling the proton from $\mathrm{C}_{4} \mathrm{~N}_{2} \mathrm{H}_{4}{ }^{\bullet+}$ ion. In fact, one of the $\mathrm{CH}^{\delta+} . . \mathrm{OH}_{2}$ bonds in PW4-c is significantly shorter (1.99 $\left.\mathrm{A}\right)$ than typical bifurcated bonds suggesting a transition towards proton transfer to generate the $\mathrm{H}^{+}\left(\mathrm{H}_{2} \mathrm{O}\right)_{4}$ ions.

The calculated structures of the hydrated protonated pyrimidine $\left(\mathrm{C}_{4} \mathrm{~N}_{2} \mathrm{H}_{5}{ }^{+}\right)\left(\mathrm{H}_{2} \mathrm{O}\right)_{n}$ clusters are significantly different from those of the hydrated radical cation. As shown in Fig. 5, hydration of protonated pyrimidine results in only externally solvated structures where the water molecules are bonded to each other and the ion is external to this solvent cluster. This is mediated by the stronger interaction that involves $\mathrm{NH}^{+} . \mathrm{OH}_{2}$ bonds similar to other ionic hydrogen bonds where the proton is shared between two centers containing lone pairs of electrons.

The lowest energy pyrimidine $\mathrm{H}^{+}\left(\mathrm{H}_{2} \mathrm{O}\right)$ isomer, $\left(\mathrm{PH}^{+} \mathrm{W} 1\right)$ in Fig. 5, has the water molecule directly attached to the $\mathrm{NH}^{+}$center via a $\mathrm{NH}^{+}-\mathrm{O}$ hydrogen bond of $1.67 \AA$ similar to the structure of the hydrated protonated pyridine. ${ }^{11}$ The second water molecule binds to the first water molecule by a $1.73 \AA$ hydrogen bond while the $\mathrm{NH}^{+}$— O bond shortens to $1.59 \AA$ as shown in isomer $\left(\mathrm{PH}^{+} \mathrm{W} 2\right)$ in Fig. 5. Three isomers were found for the pyrimidine $\mathrm{H}^{+}\left(\mathrm{H}_{2} \mathrm{O}\right)_{3}$ cluster with small differences in binding energies. Isomer $\left(\mathrm{PH}^{+} \mathrm{W} 3-\mathrm{a}\right)$ shows a symmetric structure where a central water molecule binds by $1.75 \AA$ hydrogen bonds to two other water molecules and to protonated pyrimidine by a shorter $\mathrm{NH}^{+}-\mathrm{O}$ bond of $1.43 \AA$. This structure is consistent with a growth pattern that could lead to dissociative proton transfer within the pyrimidine $\mathrm{H}^{+}\left(\mathrm{H}_{2} \mathrm{O}\right)_{4}$ cluster to form the closed shell solvated hydronium ion $\mathrm{H}_{3} \mathrm{O}^{+}\left(\mathrm{H}_{2} \mathrm{O}\right)_{3}$ as observed experimentally.

\section{Stepwise solvation of protonated pyrimidine with methanol and acetonitrile}

Figures 6(a) and 6(b) display the mass spectra obtained following the injection of protonated pyrimidine into the drift cell containing methanol and acetonitrile vapors, respectively, at various pressures and temperatures as indicated in Figs. 6(a) and 6(b). In the case of methanol the main series observed are the $\mathrm{C}_{4} \mathrm{~N}_{2} \mathrm{H}_{5}{ }^{+}\left(\mathrm{CH}_{3} \mathrm{OH}\right)_{\mathrm{n}}$ with $\mathrm{n}=1-3$ and the protonated methanol clusters $\mathrm{H}^{+}\left(\mathrm{CH}_{3} \mathrm{OH}\right)_{n}$ with $\mathrm{n}=3-6$, and both series shift towards higher $\mathrm{n}$ as the temperature of the drift cell decreases. However, in the case of acetonitrile, only the $\mathrm{C}_{4} \mathrm{~N}_{2} \mathrm{H}_{5}{ }^{+}\left(\mathrm{CH}_{3} \mathrm{CN}\right)_{\mathrm{n}}$ series with $\mathrm{n}=1-3$ is observed as shown in Fig. 6(b).

The formation of protonated methanol clusters, with $\mathrm{n}$ = 3-6 as shown in Fig. 6(a), is attributed to the dissociative proton transfer reactions (4), similar to reactions (2) and (3) observed in the hydration reactions above,

$$
\begin{aligned}
& {\left[\mathrm{H}^{+} \mathrm{C}_{4} \mathrm{H}_{4} \mathrm{~N}_{2}\left(\mathrm{CH}_{3} \mathrm{OH}\right)_{\mathrm{n}-1}\right]+\mathrm{CH}_{3} \mathrm{OH}} \\
& \quad \rightarrow \mathrm{C}_{4} \mathrm{H}_{4} \mathrm{~N}_{2}+\left[\mathrm{H}^{+}\left(\mathrm{CH}_{3} \mathrm{OH}\right)_{\mathrm{n}}\right] ; \mathrm{n} \geq 3 .
\end{aligned}
$$

The observation of reaction (4) for $\mathrm{n} \geq 3$ is a direct consequence for the higher PA of methanol $(180 \mathrm{kcal} / \mathrm{mol})^{31}$ as compared to water $(165 \mathrm{kcal} / \mathrm{mol}),{ }^{31}$ and therefore only three methanol molecules connected by $\mathrm{H}$-bonding are able to extract the proton from the protonated pyrimidine site to the methanol subcluster to generate the protonated methanol clusters $\mathrm{H}^{+}\left(\mathrm{CH}_{3} \mathrm{OH}\right)_{\mathrm{n}}$ with $\mathrm{n}=3-6$.

The absence of the deprotonation channel within the $\mathrm{C}_{4} \mathrm{~N}_{2} \mathrm{H}_{5}{ }^{+}\left(\mathrm{CH}_{3} \mathrm{CN}\right)_{n}$ clusters can be explained by the inability of acetonitrile molecules to form extended hydrogen bonding structures such as those formed by water and methanol due to the presence of the methyl groups which block the extension of hydrogen bonding networks.

Under the experimental conditions listed in Figs. 6(a) and 6(b), equilibrium could be established as indicated by the identical ATDs of the reactant and product ions as shown in Figs. $\mathrm{S} 4$ and $\mathrm{S} 5$ for the $\mathrm{C}_{4} \mathrm{~N}_{2} \mathrm{H}_{5}{ }^{+}\left(\mathrm{CH}_{3} \mathrm{OH}\right)_{\mathrm{n}}$ and $\mathrm{C}_{4} \mathrm{~N}_{2} \mathrm{H}_{5}{ }^{+}\left(\mathrm{CH}_{3} \mathrm{CN}\right)_{n}$ clusters, respectively (supplementary material). ${ }^{28}$ The equilibrium constants for the stepwise hydration of the $\mathrm{C}_{4} \mathrm{~N}_{2} \mathrm{H}_{5}{ }^{+}$ions with 1-3 methanol and acetonitrile molecules are measured at different temperatures and the resulting van't Hoff plots for the formation of $\mathrm{C}_{4} \mathrm{~N}_{2} \mathrm{H}_{5}{ }^{+}\left(\mathrm{CH}_{3} \mathrm{OH}\right)_{\mathrm{n}}$ with $\mathrm{n}=1-3$ and $\mathrm{C}_{4} \mathrm{~N}_{2} \mathrm{H}_{5}{ }^{+}\left(\mathrm{CH}_{3} \mathrm{CN}\right)_{\mathrm{n}}$ with $\mathrm{n}=2-3$ clusters are shown in Figs. 7(a) and 7(b), respectively. The measured $\Delta \mathrm{H}^{\circ}$ and $\Delta \mathrm{S}^{\circ}$ values are reported in Table II. Because of the higher binding energy of the $\mathrm{C}_{4} \mathrm{~N}_{2} \mathrm{H}_{5}{ }^{+}\left(\mathrm{CH}_{3} \mathrm{CN}\right)$ complex and the need to conduct the equilibrium measurements at higher temperatures, it was not possible to obtain a van't Hoff plot for the formation of the $\mathrm{C}_{4} \mathrm{~N}_{2} \mathrm{H}_{5}{ }^{+}\left(\mathrm{CH}_{3} \mathrm{CN}\right)$ complex under our experimental conditions. Instead, we were able to measure $\Delta \mathrm{G}^{\circ}$ at one temperature $(350 \mathrm{~K})$, and using $\Delta \mathrm{S}^{\circ}$ of $28 \mathrm{cal} / \mathrm{mol} \mathrm{K}$, we can estimate $\Delta \mathrm{H}^{\circ}$ for the formation of the $\mathrm{C}_{4} \mathrm{~N}_{2} \mathrm{H}_{5}{ }^{\bullet+}\left(\mathrm{CH}_{3} \mathrm{CN}\right)$ complex as 
(a)

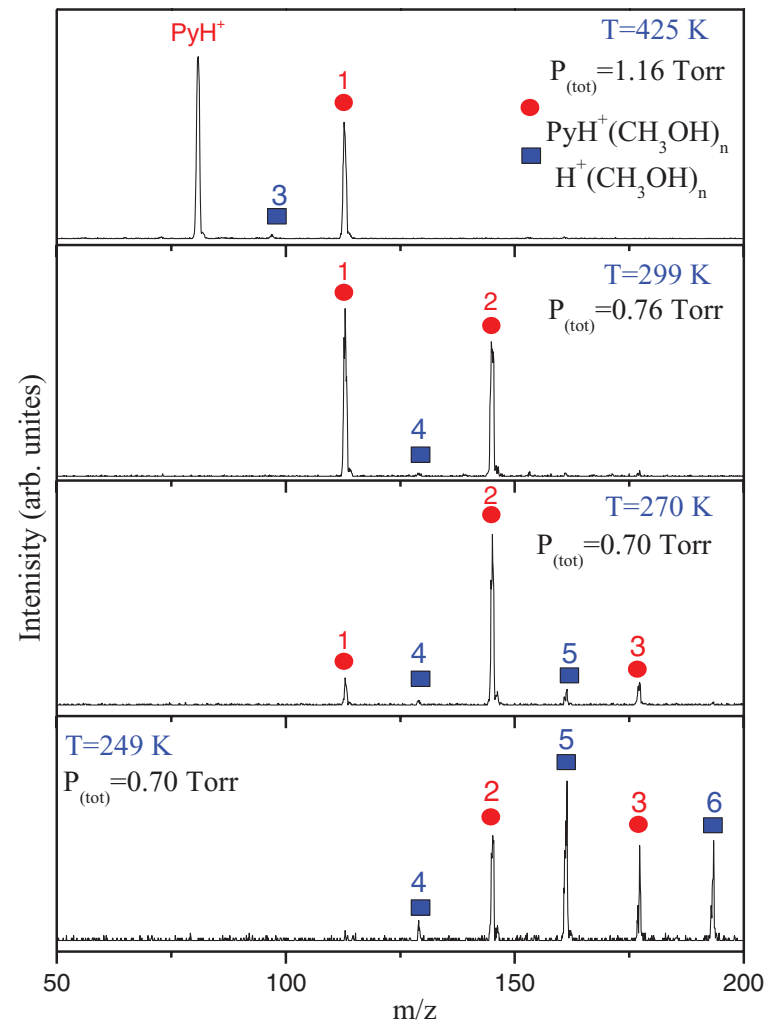

(b)

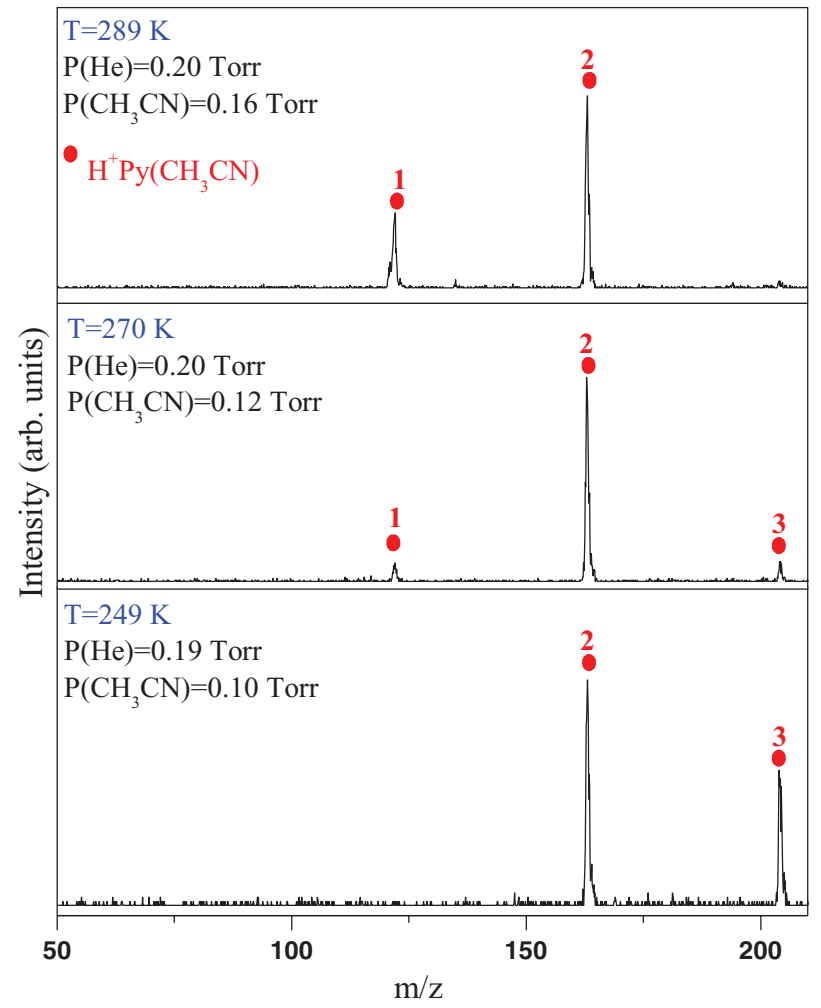

FIG. 6. Mass spectra resulting from the injection of mass-selected protonated pyrimidine $\left(\mathrm{H}^{+} \mathrm{Py}\right)$ into (a) helium $(\mathrm{He})-\mathrm{methanol}\left(\mathrm{CH}_{3} \mathrm{OH}\right)$ and $(\mathrm{b})$ helium $(\mathrm{He})$-acetonitrile $\left(\mathrm{CH}_{3} \mathrm{CN}\right)$ vapor mixtures at different temperatures and pressures as indicated.

$22.3 \mathrm{kcal} / \mathrm{mol}$ which is in good agreement with the calculated value of $22.8 \mathrm{kcal} / \mathrm{mol}$ shown in Table II.

\section{Calculated structures of methanol and acetonitrile clusters with protonated pyrimidine}

Figure 8 displays the low energy structures of the $\mathrm{C}_{4} \mathrm{~N}_{2} \mathrm{H}_{5}+\left(\mathrm{CH}_{3} \mathrm{OH}\right)_{n}$ clusters calculated at the M06-2X/6$311++\mathrm{G}(\mathrm{d}, \mathrm{p})$ level. The lowest energy structure of the $\mathrm{C}_{4} \mathrm{~N}_{2} \mathrm{H}_{5}{ }^{+}\left(\mathrm{CH}_{3} \mathrm{OH}\right)$ complex $\left(\mathrm{PH}^{+} \mathrm{M} 1-\mathrm{a}\right.$ in Fig. 8) shows a proton-bound dimer with a short $\mathrm{NH}^{+}-\mathrm{O}$ hydrogen bond of $1.59 \AA$ consistent with a large calculated binding energy of $19.6 \mathrm{kcal} / \mathrm{mol}$ which is a little overestimated from

TABLE II. Measured thermochemistry $\left(\Delta \mathrm{H}^{\circ} \mathrm{n}-1, \mathrm{n}\right.$ and $\left.\Delta \mathrm{S}_{\mathrm{n}-1, \mathrm{n}}\right)$ of the formation of $\mathrm{H}^{+}$pyrimidine $\left(\mathrm{CH}_{3} \mathrm{OH}\right)_{n}$ and $\mathrm{H}^{+}$pyrimidine $\left(\mathrm{CH}_{3} \mathrm{CN}\right)_{n}$ clusters; with $n=1-3$. The calculated binding energies (BE) of the lowest energy isomers are shown for comparison.

\begin{tabular}{|c|c|c|c|c|c|c|}
\hline \multirow[b]{2}{*}{$\mathrm{n}$} & \multicolumn{3}{|c|}{$\mathrm{H}^{+}$Pyrimidine $\left(\mathrm{CH}_{3} \mathrm{OH}\right)_{n}$} & \multicolumn{3}{|c|}{$\mathrm{H}^{+}$Pyrimidine $\left(\mathrm{CH}_{3} \mathrm{CN}\right)_{\mathrm{n}}$} \\
\hline & $-\Delta \mathrm{H}^{\mathrm{o} a}$ & $-\Delta S^{o b}$ & $\mathrm{BE}^{\mathrm{c}}$ & $-\Delta \mathrm{H}^{\mathrm{o} a}$ & $-\Delta S^{o b}$ & $\mathrm{BE}^{\mathrm{c}}$ \\
\hline 1 & 18.2 & 26.9 & $21.4(19.6)$ & $\mathrm{n} / \mathrm{a}$ & $\mathrm{n} / \mathrm{a}$ & $23.7(22.8)$ \\
\hline 2 & 12.8 & 27.4 & $15.8(15.1)$ & 13.0 & 26.3 & 14.5 (12.9) \\
\hline 3 & 11.8 & 31.3 & $12.9(11.2)$ & 11.2 & 27.9 & $13.5(13.4)$ \\
\hline
\end{tabular}

${ }^{\mathrm{a}} \Delta \mathrm{H}^{\circ}{ }_{\mathrm{n}-1, \mathrm{n}}$ units are $\mathrm{kcal} / \mathrm{mol}$.

${ }^{\mathrm{b}} \Delta \mathrm{S}_{\mathrm{n}-1, \mathrm{n}}^{\circ}$ units are $\mathrm{cal} / \mathrm{molK}$.

${ }^{\mathrm{c}} \mathrm{BE}$ (Binding energy - calculated by DFT at the M06-2x/6-311++G (d,p) level (corrected for ZPE and BSSE). the measured value of $18.2 \mathrm{kcal} / \mathrm{mol}$. However, the protonbound dimer structure is clearly the most stable structure as the carbon-based bifurcated $\mathrm{CH}^{\delta+}-\mathrm{O}$ structure $\left(\mathrm{PH}^{+} \mathrm{M} 1-\right.$ $\mathrm{b}$ in Fig. 8) has significantly lower binding energy (10.6 $\mathrm{kcal} / \mathrm{mol})$. For the $\mathrm{C}_{4} \mathrm{~N}_{2} \mathrm{H}_{5}{ }^{+}\left(\mathrm{CH}_{3} \mathrm{OH}\right)_{2}$ cluster, three structures were found with the hydrogen-bonding chain $\left(\mathrm{PH}^{+} \mathrm{M} 2-\right.$ a) giving the highest binding energy $(15.1 \mathrm{kcal} / \mathrm{mol})$ which is again overestimated as compared to the experimental value of $12.8 \mathrm{kcal} / \mathrm{mol}$. The other two structures show proton sharing between the two methanol molecules $\left(\mathrm{PH}^{+} \mathrm{M} 2-\mathrm{b}\right)$ and a combination of $\mathrm{NH}^{+}-\mathrm{O}$ and $\mathrm{CH}^{\delta+}-\mathrm{O}$ hydrogen bonding interactions $\left(\mathrm{PH}^{+} \mathrm{M} 2-\mathrm{c}\right)$. The lowest energy structure of the $\mathrm{C}_{4} \mathrm{~N}_{2} \mathrm{H}_{5}{ }^{+}\left(\mathrm{CH}_{3} \mathrm{OH}\right)_{3}$ cluster involves a cyclic hydrogen bonding structure of the three methanol molecules $\left(\mathrm{PH}^{+} \mathrm{M} 3-\mathrm{a}\right)$ which results in a binding energy of $11.2 \mathrm{kcal} / \mathrm{mol}$, in a good agreement with the measured value of $11.8 \mathrm{kcal} / \mathrm{mol}$. The other two structures shown in Fig. 8 represent a combination of $\mathrm{NH}^{+}-\mathrm{O}$ and $\mathrm{CH}^{\delta+}-\mathrm{O}$ hydrogen structures $\left(\mathrm{PH}^{+} \mathrm{M} 3-\mathrm{b}\right)$ and a proton-shared structure $\left(\mathrm{PH}^{+} \mathrm{M} 3-\mathrm{c}\right)$ both with significantly lower binding energies than the $\mathrm{PH}^{+} \mathrm{M} 3-$ a structure.

The calculated low energy structures of the $\mathrm{C}_{4} \mathrm{~N}_{2} \mathrm{H}_{5}{ }^{+}\left(\mathrm{CH}_{3} \mathrm{CN}\right)_{\mathrm{n}}$ clusters are shown in Fig. 9. Similar to the water and methanol clusters, the lowest energy structure for $\mathrm{n}=1$ is the proton-bound dimer $\left(\mathrm{C}_{4} \mathrm{~N}_{2} \mathrm{H}_{4}\right) \mathrm{H}^{+} \mathrm{NCCH}_{3}$ with a binding energy of $22.8 \mathrm{kcal} / \mathrm{mol}$ as compared to the experimentally estimated value of $22.3 \mathrm{kcal} / \mathrm{mol}$. The calculated lowest energy structure of the $\left(\mathrm{C}_{4} \mathrm{~N}_{2} \mathrm{H}_{4}\right) \mathrm{H}^{+}\left(\mathrm{CH}_{3} \mathrm{CN}\right)_{2}$ cluster $\left(\mathrm{PH}^{+} \mathrm{A} 2\right.$-a in Fig. 9$)$ shows that the second acetonitrile molecule shares the proton of the protonated pyrimidine with 

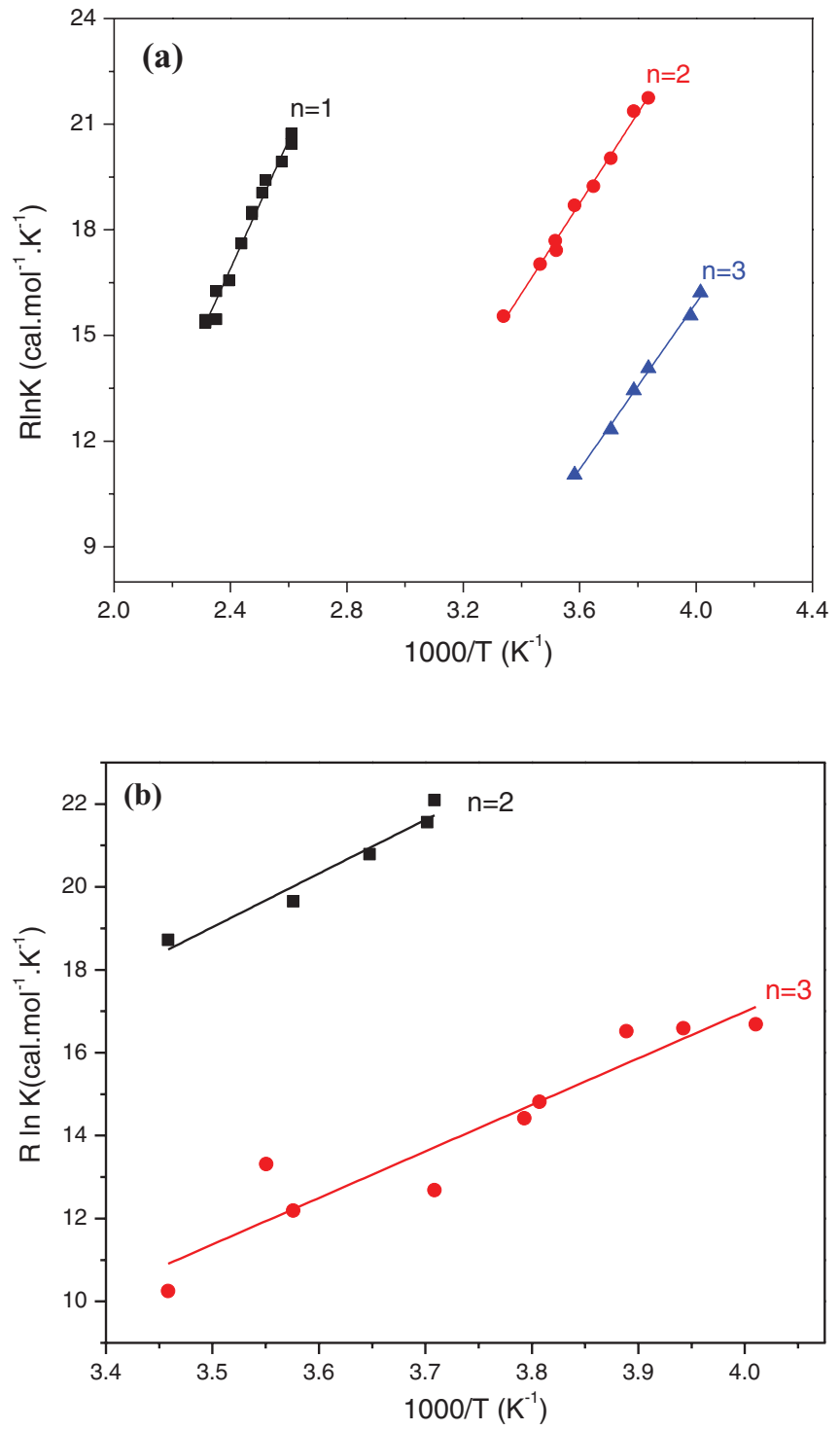

FIG. 7. Van't Hoff plots of the temperature dependence of the equilibrium constant of the stepwise formation of (a) $\mathrm{H}^{+}$pyrimidine $\left(\mathrm{CH}_{3} \mathrm{OH}\right)_{n}$ clusters; with $\mathrm{n}=1-3$ and (b) $\mathrm{H}^{+}$pyrimidine $\left(\mathrm{CH}_{3} \mathrm{CN}\right)_{n}$ clusters with $\mathrm{n}=2-3$.

the first acetonitrile molecule through relatively long bonds $(2.12 \AA)$, and a binding energy of $12.9 \mathrm{kcal} / \mathrm{mol}$ in excellent agreement with the measured value of $13.0 \mathrm{kcal} / \mathrm{mol}$. The other two structures $\left(\mathrm{PH}^{+} \mathrm{A} 2-\mathrm{b}\right.$ and $\mathrm{PH}^{+} \mathrm{A} 2$-c in Fig. 9) show binding through the weak $\mathrm{CH}^{\delta+}-\mathrm{N}$ hydrogen bonds to the pyrimidine ring hydrogens. For the $\left(\mathrm{C}_{4} \mathrm{~N}_{2} \mathrm{H}_{4}\right) \mathrm{H}^{+}\left(\mathrm{CH}_{3} \mathrm{CN}\right)_{3}$ cluster, the three lowest energy structures $\left(\mathrm{PH}^{+} \mathrm{A} 3-\mathrm{a}\right.$, $\mathrm{PH}^{+} \mathrm{A} 3-\mathrm{b}$, and $\mathrm{PH}^{+} \mathrm{A} 3-\mathrm{c}$ in Fig. 9) consist of multiple $\mathrm{CH}^{\delta+}-\mathrm{N}$ hydrogen bonds in bifurcated structures that lead to binding energies $(13.4-12.5 \mathrm{kcal} / \mathrm{mol})$ higher than the measured value of $11.2 \mathrm{kcal} / \mathrm{mol}$.

\section{E. Trends in binding energies and effect of solvent}

Figure 10 illustrates the variations of $\Delta \mathrm{H}_{\mathrm{n}-1, \mathrm{n}}^{\circ}$ vs. $\mathrm{n}$ for the studied systems. Since the van't Hoff plot for the formation of $\left(\mathrm{C}_{4} \mathrm{~N}_{2} \mathrm{H}_{4}\right) \mathrm{H}^{+}\left(\mathrm{CH}_{3} \mathrm{CN}\right)$ could not be obtained due to vanishing intensity of the $\left(\mathrm{C}_{4} \mathrm{~N}_{2} \mathrm{H}_{4}\right) \mathrm{H}^{+}$ion since the equi-

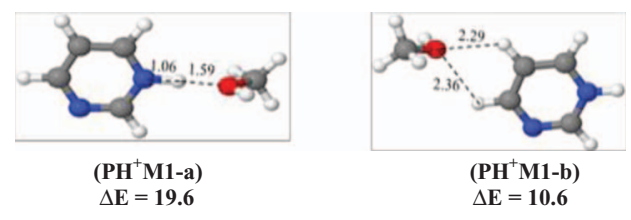

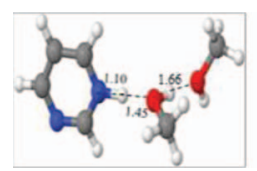

(PH ${ }^{+}$2-a)

$\Delta \mathbf{E}=15.1$

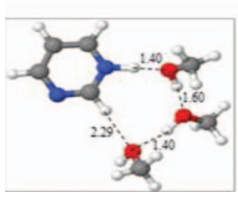

(PH ${ }^{+}$M3-a)

$\Delta \mathrm{E}=\mathbf{1 1 . 2}$

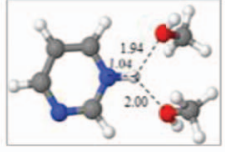

(PH ${ }^{+}$M-b)

$\Delta \mathbf{E}=\mathbf{1 0 . 7}$

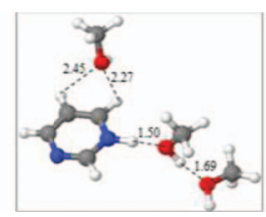

(PH ${ }^{+}$M-b)

$\Delta \mathbf{E}=\mathbf{8 . 7}$

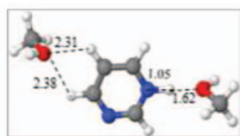

(PH ${ }^{+}$M2-c)

$\Delta \mathrm{E}=\mathbf{8 . 8}$

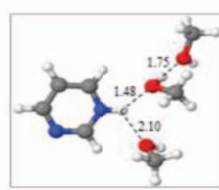

(PH ${ }^{+}$M3-c)

$\Delta \mathbf{E}=8.6$
FIG. 8. Structures of the $\mathrm{H}^{+}$Pyrimidine $\left(\mathrm{CH}_{3} \mathrm{OH}\right)_{n}$ clusters $\left(\mathrm{PH}^{+} \mathrm{Mn}\right)$ with $\mathrm{n}=1-3$ calculated by DFT at the M06-2x/6-311++G $(\mathrm{d}, \mathrm{p})$ level. Binding energies $(\triangle \mathrm{E})$ are corrected for zero-point energies (ZPE) and basis-set super position errors (BSSE). Energies are in $\mathrm{kcal} / \mathrm{mol}$. Distances are in Angstrom.

librium is shifted to higher clusters, we used the calculated binding energy $(22.8 \mathrm{kcal} / \mathrm{mol})$ instead of $\Delta \mathrm{H}^{\circ}$ in Fig. 10. The data show that acetonitrile forms a stronger proton-bound dimer than methanol and water with the protonated pyrimidine. This is a consequence of the strong dipole moment

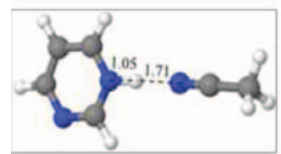

(PH ${ }^{+} \mathbf{A 1}$

$\Delta \mathbf{E}=\mathbf{2 2 . 8}$

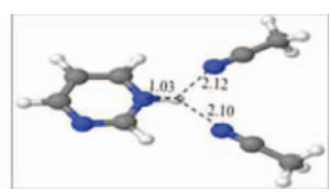

(PH ${ }^{+} \mathbf{A 2 - a )}$
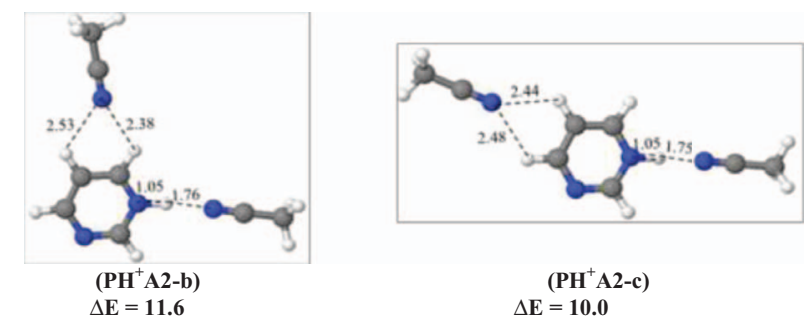

$\Delta \mathrm{E}=11.6$

$$
\begin{aligned}
\left(\mathrm{PH}^{+} \mathrm{A2}-\mathrm{c}\right) \\
\Delta \mathrm{E}=\mathbf{1 0 . 0}
\end{aligned}
$$

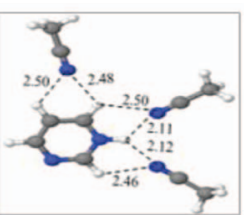

(PH ${ }^{+} \mathbf{A 3 - a )}$ $\Delta \mathbf{E}=13.4$

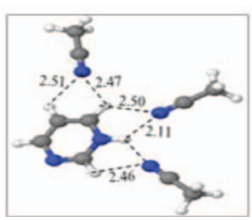

(PH ${ }^{+}$A3-b) $\Delta E=12.6$

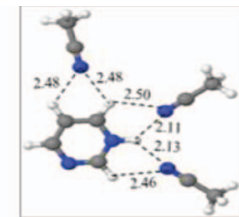

( $\mathrm{PH}^{+}$A3-c)

FIG. 9. Structures of the $\mathrm{H}^{+}$Pyrimidine $\left(\mathrm{CH}_{3} \mathrm{CN}\right)_{n}$ clusters $\left(\mathrm{PH}^{+} \mathrm{An}\right)$ with $\mathrm{n}=1-3$ calculated by DFT at the M06-2x/6-311++G (d,p) level. Binding energies $(\triangle \mathrm{E})$ are corrected for zero-point energies (ZPE) and basis-set super position errors (BSSE). Energies are in $\mathrm{kcal} / \mathrm{mol}$. Distances are in Angstrom. 


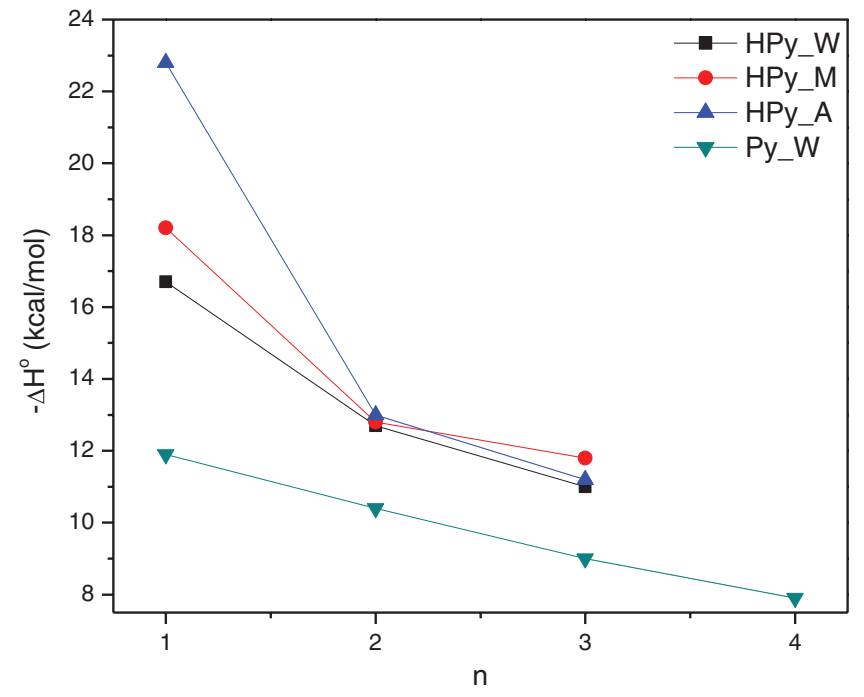

FIG. 10. Measured $\Delta \mathrm{H}^{\circ} \mathrm{n}$ vs $\mathrm{n}$ for the formation of pyrimidine $\mathrm{H}^{+}(\mathrm{X})_{\mathrm{n}}$ clusters with $\mathrm{X}=$ water $(\mathrm{W})$, methanol $(\mathrm{M})$, and acetonitrile $(\mathrm{A})$ and $\mathrm{n}=1-3$. For comparison, $\Delta \mathrm{H}^{\circ}{ }_{\mathrm{n}}$ values for the hydration of pyrimidine radical cation with 1-4 water molecules are also included $\left(\mathrm{Py}-\mathrm{W}_{\mathrm{n}}\right)$.

of acetonitrile (3.9 D) as compared to $1.7 \mathrm{D}$ and $1.6 \mathrm{D}$ for methanol and water, respectively. As a result, the ion-dipole interaction term is stronger in the case of acetonitrile, and the overall binding energy is significantly higher than those of methanol and water. The sequential binding energies in all cases follow the trend of decreasing $\Delta \mathrm{H}^{\circ}{ }_{\mathrm{n}-1, \mathrm{n}}$ with increasing $\mathrm{n}$ which can be expected for association reactions dominated by ion-dipole interactions including ionic hydrogen bonding. ${ }^{1}$ However, Fig. 10 shows that the decrease in $\Delta \mathrm{H}^{\circ}{ }_{\mathrm{n}-1, \mathrm{n}}$ vs. $\mathrm{n}$ plot is more regular in the hydration of the radical cation than in the hydration of the protonated pyrimidine or its stepwise association with methanol and acetonitrile molecules. This is due to the change in the nature of bonding from weak carbonbased $\mathrm{CH}^{\delta+}-\mathrm{O}$ hydrogen bonds in case of the radical cation to stronger $\mathrm{NH}^{+}-\mathrm{O}$ ionic hydrogen bonds with protonated pyrimidine.

Figure 10 also shows a significant drop in the binding energy (43\%) upon the addition of the second acetonitrile molecule to the proton-bound dimer $\left(\mathrm{C}_{4} \mathrm{~N}_{2} \mathrm{H}_{4}\right) \mathrm{H}^{+}\left(\mathrm{NCCH}_{3}\right)$ as compared to the methanol and water interactions where the corresponding drops in binding energies are $30 \%$ and $24 \%$, respectively. The transition from strong ionic hydrogen bonding in the proton-bound dimer to weaker $\mathrm{CH}^{\delta+}-\mathrm{N}$ type of bonds is responsible for the sharp drop in the binding energy of the $\left(\mathrm{C}_{4} \mathrm{~N}_{2} \mathrm{H}_{4}\right) \mathrm{H}^{+}\left(\mathrm{CH}_{3} \mathrm{CN}\right)_{2}$ cluster. However, in the case of water and methanol extended hydrogen bonding networks can be formed as shown in the calculated low energy structures of the $\left(\mathrm{C}_{4} \mathrm{~N}_{2} \mathrm{H}_{4}\right) \mathrm{H}^{+}\left(\mathrm{H}_{2} \mathrm{O}\right)_{2}$ and $\left(\mathrm{C}_{4} \mathrm{~N}_{2} \mathrm{H}_{4}\right) \mathrm{H}^{+}\left(\mathrm{CH}_{3} \mathrm{OH}\right)_{2}$ clusters displayed in Figs. 5 and 8, respectively.

\section{F. Ion mobility measurements of the proton-bound dimers}

To verify the structures of the proton-bound dimers $\left(\mathrm{C}_{4} \mathrm{~N}_{2} \mathrm{H}_{4}\right) \mathrm{H}^{+}(\mathrm{X})$ for $\mathrm{X}=\mathrm{H}_{2} \mathrm{O}, \mathrm{CH}_{3} \mathrm{OH}$, and $\mathrm{CH}_{3} \mathrm{CN}$, we measured the mobility of the mass-selected ions generated
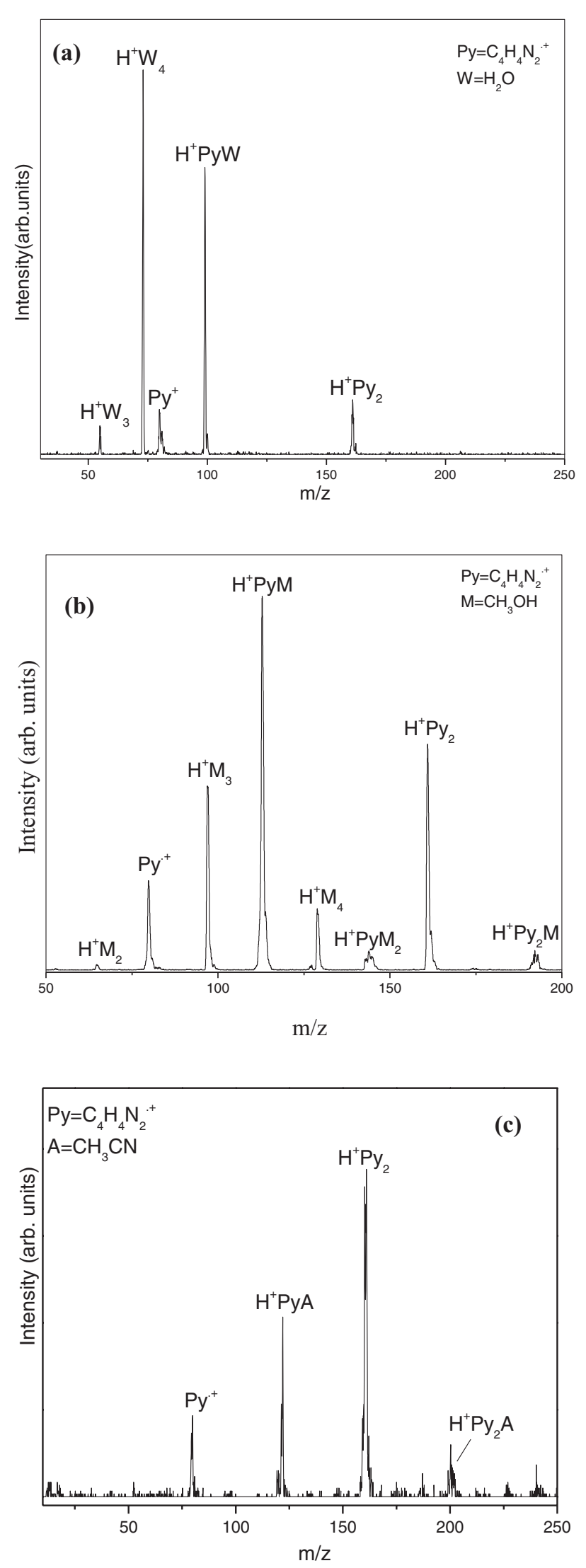

FIG. 11. Mass spectra resulting from the injection of the EI ionized binary clusters of (a) pyrimidine-water, (b) pyrimidine-methanol, and (c) pyrimidine-acetonitrile into the drift cell containing (a) 0.93 Torr helium at $298 \mathrm{~K}$, (b) 0.83 Torr helium at $300 \mathrm{~K}$, and (c) 1.23 Torr helium at $302 \mathrm{~K}$. 
by EI ionization of the binary pyrimidine-water, pyrimidinemethanol, and pyrimidine-acetonitrile clusters. The mass spectra of the ionized binary clusters are shown in Fig. 11, and ATDs of the mass-selected proton-bound dimers as a function of the drift field are provided in Fig. S6 (supplementary material). ${ }^{28}$

The mass spectra displayed in Fig. 11 show the formation of the proton-bound mixed dimers $\left(\mathrm{C}_{4} \mathrm{~N}_{2} \mathrm{H}_{4}\right) \mathrm{H}^{+}(\mathrm{X})$ for $\mathrm{X}=\mathrm{H}_{2} \mathrm{O}, \mathrm{CH}_{3} \mathrm{OH}$, and $\mathrm{CH}_{3} \mathrm{CN}$ in addition to the pyrimidine homodimer $\left(\mathrm{C}_{4} \mathrm{~N}_{2} \mathrm{H}_{4}\right) \mathrm{H}^{+}\left(\mathrm{C}_{4} \mathrm{~N}_{2} \mathrm{H}_{4}\right)$. Following the EI ionization of the binary neutral clusters, intracluster proton transfer reactions generate the proton-bound dimers in addition to higher protonated clusters. The energy released from exothermicity of these reactions is dissipated by evaporative cooling where weakly bound neutral molecules are evaporated from the cluster. This mechanism acts as a third-body effect in the sequential association reactions studied in the drift tube as described in Secs. I-III.

In the experiment to measure ion mobility, a packet of the mass selected ions of interest is injected into the drift cell and the arrival time distribution ATD is collected at varying cell voltages, $V$ (with $T$ and $P$ held constant), where $T$ is the buffer gas temperature $(\mathrm{K})$ and $P$ is the buffer gas pressure (Torr). ${ }^{20,21}$ The reduced mobility $K_{o}$ is obtained from the plot of the drift time $\left(t_{d}\right)$ versus P/V which according to Eq. (5) gives a straight line with slope containing $K_{o}$ and an intercept corresponding to $t_{o}$, the effective time spent outside the drift cell. All the mobility measurements were carried out in the low-field limit where the ion's drift velocity is small compared to the thermal velocity and the ion mobility is independent of the field strength $(E / N<6.0$, where $E$ is the electric field intensity and $N$ is the gas number density and $E / N$ is expressed in units of Townsend (Td) where $1 \mathrm{Td}=10^{-17}$ $\mathrm{V} \mathrm{cm}{ }^{2},{ }^{32}$

$$
t_{d}=\left(\frac{z^{2} \times 273.15}{T \times 760 \times K_{o}}\right)\left(\frac{P}{V}\right)+t_{o}
$$

The average collision cross section, $\Omega^{(1.1)}$, of the ions in the helium buffer gas is calculated according to the kinetic theory as shown in Eq. (6),

$$
K=\frac{3 q e}{16 N}\left(\frac{2 \pi}{k_{B} T_{e f f}}\right)^{\frac{1}{2}}\left(\frac{M_{i}+M_{b}}{M_{i} M_{b}}\right)^{\frac{1}{2}} \frac{1}{\Omega_{a v g}^{(1,1)}}
$$

where qe is the ion charge, $N$ is the number density of the buffer gas, $T_{\text {eff }}$ is the effective temperature, $M_{i}$ and $M_{b}$ are the masses of the ion and buffer gas, respectively, and $\Omega_{\text {avg }}^{(1,1)}$ is the orientationally averaged collision integral. The resulting reduced mobility $K_{0}$ and the corresponding collisional cross sections of the proton-bound dimers are shown in Table III. It is clear that measured collision cross sections are in excellent agreement with those calculated based on the lowest energy structures of the proton-bound dimers. This provides experimental-based support for the DFT structures obtained at the M06-2x/6-311++G (d,p) level.
TABLE III. Mobility and collision cross sections in helium of the pyrimidine radical cation, protonated pyrimidine, and the proton-bound dimers $\left(\mathrm{C}_{4} \mathrm{~N}_{2} \mathrm{H}_{4}\right) \mathrm{H}^{+}(\mathrm{X})$ with $\mathrm{X}=\mathrm{H}_{2} \mathrm{O}, \mathrm{CH}_{3} \mathrm{OH}$, and $\mathrm{CH}_{3} \mathrm{CN}$.

\begin{tabular}{lrrrrc}
\hline \hline Ion & $\mathrm{T}(\mathrm{K})$ & $\mathrm{K}_{0 \text { (expt.) }}{ }^{\mathrm{a}}$ & $\Omega_{\text {(expt.) }}{ }^{\mathrm{b}}$ & $\mathrm{K}_{0 \text { (calc.) }}{ }^{\mathrm{c}, \mathrm{a}}$ & $\Omega_{\text {(calc.) }}{ }^{\mathrm{c}, \mathrm{b}}$ \\
\hline Pyrimidine & 299 & 12.2 & 44.9 & 12.3 & 44.5 \\
$\mathrm{H}^{+}$Pyrimidine & 301 & 11.8 & 46.1 & 12.1 & 45.1 \\
$\mathrm{H}^{+}$Pyrimidine $\left(\mathrm{H}_{2} \mathrm{O}\right)$ & 300 & 10.4 & 52.3 & 10.0 & 54.7 \\
$\mathrm{H}^{+}$Pyrimidine $\left(\mathrm{CH}_{3} \mathrm{OH}\right)$ & 300 & 8.6 & 63.0 & 8.9 & 61.1 \\
$\mathrm{H}^{+}$Pyrimidine $\left(\mathrm{CH}_{3} \mathrm{CN}\right)$ & 302 & 8.1 & 66.8 & 8.2 & 66.0 \\
\hline \hline
\end{tabular}

${ }^{\mathrm{a}} \mathrm{K}_{0}$ in $\mathrm{cm}^{2} \mathrm{~V}^{-1} \mathrm{~s}^{-1}$.

${ }^{\mathrm{b}} \Omega$ in $\AA^{2}$.

${ }^{\mathrm{c}}$ Calculated by Mobcal (Ref. 29) at $300 \mathrm{~K}$ based on the lowest energy structures obtained from DFT at the M06-2x/6-311++G (d,p) level

\section{SUMMARY AND CONCLUSIONS}

Equilibrium thermochemical measurements using an ion mobility drift cell technique have been utilized to investigate the binding energies and entropy changes associated with the stepwise hydration of the pyrimidine radical cation and protonated pyrimidine. The binding energy of the hydrated pyrimidine radical cation is weaker than that of the protonbound dimer pyrimidine $\mathrm{H}^{+}\left(\mathrm{H}_{2} \mathrm{O}\right)$ consistent with the formation of a weak carbon-based $\mathrm{CH}^{\delta+} . \cdot \mathrm{OH}_{2}$ hydrogen bond $(11.9 \mathrm{kcal} / \mathrm{mol})$ and a stronger $\mathrm{NH}^{+} \cdot . \mathrm{OH}_{2}$ hydrogen bond $(15.6 \mathrm{kcal} / \mathrm{mol})$, respectively. Other proton-bound dimers such as pyrimidine $\mathrm{H}^{+}\left(\mathrm{CH}_{3} \mathrm{OH}\right)$ and pyrimidine $\mathrm{H}^{+}\left(\mathrm{CH}_{3} \mathrm{CN}\right)$ exhibit higher binding energies $(18.2 \mathrm{kcal} / \mathrm{mol}$ and $22.8 \mathrm{kcal} / \mathrm{mol}$, respectively) due to the higher proton affinities and dipole moments of acetonitrile and methanol as compared to water.

DFT calculations show that the hydrated pyrimidine radical cation clusters form internally solvated structures in which the water molecules are bonded to the $\mathrm{C}_{4} \mathrm{~N}_{2} \mathrm{H}_{4}{ }^{\bullet+}$ ion by weak $\mathrm{CH}^{\delta+} \ldots \mathrm{OH}_{2}$ hydrogen bonds. The hydrated protonated pyrimidine clusters form externally solvated structures where the water molecules are bonded to each other and the ion is external to water cluster.

Dissociative proton transfer reactions $\mathrm{C}_{4} \mathrm{~N}_{2} \mathrm{H}_{4}{ }^{\bullet+}\left(\mathrm{H}_{2} \mathrm{O}\right)_{\mathrm{n}-1}+\mathrm{H}_{2} \mathrm{O} \rightarrow \mathrm{C}_{4} \mathrm{~N}_{2} \mathrm{H}_{3} \cdot+\left(\mathrm{H}_{2} \mathrm{O}\right)_{\mathrm{n}} \mathrm{H}^{+}$ and $\mathrm{C}_{4} \mathrm{~N}_{2} \mathrm{H}_{5}^{+}\left(\mathrm{H}_{2} \mathrm{O}\right)_{\mathrm{n}-1}+\mathrm{H}_{2} \mathrm{O} \rightarrow \mathrm{C}_{4} \mathrm{~N}_{2} \mathrm{H}_{4}{ }^{\bullet}+\left(\mathrm{H}_{2} \mathrm{O}\right)_{\mathrm{n}} \mathrm{H}^{+}$ are observed for $\mathrm{n} \geq 4$ where the reactions become thermoneutral or exothermic. These reactions become favorable due to the formation of the closed shell solvated hydronium ion $\mathrm{H}_{3} \mathrm{O}^{+}\left(\mathrm{H}_{2} \mathrm{O}\right)_{3}$. In case of methanol, the reaction is observed at $\mathrm{n} \geq 3$ due to the higher proton affinity of methanol as compared to water. The absence of the dissociative proton transfer reaction within the $\mathrm{C}_{4} \mathrm{~N}_{2} \mathrm{H}_{5}{ }^{+}\left(\mathrm{CH}_{3} \mathrm{CN}\right)_{\text {n }}$ clusters results from the inability of acetonitrile molecules to form extended hydrogen bonding structures such as those formed by water and methanol due to the presence of the methyl groups which block the extension of hydrogen bonding networks.

The measured collisional cross sections of the protonbound dimers provide experimental-based support for the DFT calculated structures at the M06-2x/6-311++G (d,p) level. 


\section{ACKNOWLEDGMENTS}

We thank Dr. Abdel-Rahman Soliman for the early measurements of the binding energies of the hydrated pyrimidine radical cation. We thank the National Science Foundation (NSF) (CHE-0911146) and National Aeronautics and Space Administration (NASA) (NNX07AU16G) for the support of this work. We also thank King Abdulaziz University (Saudi Arabia) for the partial support of this work.

${ }^{1}$ M. Meot-Ner (Mautner), Chem. Rev. 112, PR22-PR103 (2012).

${ }^{2} \mathrm{~S}$. Tsuzuki, in Intermolecular Forces and Clusters I, edited by D. J. Wales (Springer, Berlin, Heidelberg, 2005), Vol. 115, p. 149.

${ }^{3}$ J. Cerny and P. Hobza, Phys. Chem. Chem. Phys. 9, 5291 (2007).

${ }^{4}$ G. A. Jeffrey, An Introduction to Hydrogen Bonding (Oxford University press, Oxford, 1997).

${ }^{5}$ B. E. Conway, Ionic Hydration in Chemistry and Biophysics (Elsevier, Amsterdam, New York, 1981).

${ }^{6}$ M. P. Bernstein, S. A. Sandford, L. J. Allamandola, J. S. Gillette, S. J. Clemett, and R. N. Zare, Science 283, 1135-1138 (1999).

${ }^{7}$ M. Nuevo, S. N. Milam, S. A. Sandford, J. E. Elsila, and J. P. Dworkin, Astrobiology 9, 683-695 (2009).

${ }^{8}$ C. Menor-Salvan and M. R. Marin-Yaseli, Chem. Soc. Rev. 41, 5404-5415 (2012).

${ }^{9}$ Y. Ibrahim, E. Alsharaeh, K. Dias, M. Meot-Ner, and M. S. El-Shall, J. Am. Chem. Soc. 126, 12766-12767 (2004)

${ }^{10}$ Y. Ibrahim, E. Alsharaeh, M. Meot-Ner, M. S. El-Shall, and S. Scheiner, J. Am. Chem. Soc. 127, 7053-7064 (2005).

${ }^{11}$ Y. Ibrahim, R. Mabrouki, M. Meot-Ner, and M. S. El-Shall, J. Phys. Chem. A 111, 1006-1014 (2007).

${ }^{12}$ L. J. Haupert and P. G. Enthold, J. Phys. Chem. A 117, 1164-1170 (2013).

${ }^{13}$ T. Wyttenbach and M. T. Bowers, Chem. Phys. Lett. 480, 1-16 (2009).

${ }^{14}$ B. Gao, T. Wyttenbach, and M. T. Bowers, J. Am. Chem. Soc. 131, 46954701 (2009)
${ }^{15}$ D. Liu, T. Wyttenbach, and M. T. Bowers, J. Am. Chem. Soc. 128, 1515515163 (2006).

${ }^{16}$ P. O. Momoh and M. S. El-Shall, Phys. Chem. Chem. Phys. 10, 4827-4834 (2008).

${ }^{17}$ R. Mabrouki, Y. Ibrahim, E. Xie, M. Meot-Ner, and M. S. El-Shall, J. Phys. Chem. A 110, 7334-7344 (2006).

${ }^{18}$ P. O. Momoh and M. S. El-Shall, Chem. Phys. Lett. 436, 25-29 (2007).

${ }^{19}$ P. O. Momoh, E. Xie, S. A. Abrash, M. Meot-Ner, and M. S. El-Shall, J. Phys. Chem. A 112, 6066-6073 (2008).

${ }^{20}$ P. O. Momoh, A. M. Hamid, S. A. Abrash, and M. S. El-Shall, J. Chem. Phys. 134, 204315 (2011).

${ }^{21}$ P. O. Momoh, S. A. Abrash, R. Mabrouki, and M. S. El-Shall, J. Am. Chem. Soc. 128, 12408-12409 (2006).

${ }^{22}$ S. Melandri, M. E. Sanz, W. Caminzti, P. G. Favero, and Z. Kisiel, J. Am. Chem. Soc. 120, 11504 (1998).

${ }^{23}$ H. Abe, Y. Ohyanagi, M. Ichijo, N. Mikami, and M. Ito, J. Chem. Phys. 89, 3512 (1985).

${ }^{24}$ N. Mikami, Y. Sugahara, and M. Ito, J. Phys. Chem. 90, 2080 (1986).

${ }^{25}$ A. Destexhe, J. Smets, L. Adamowicz, and G. Maes, J. Phys. Chem. 98, 1506 (1994).

${ }^{26}$ B. Zhang, Y. Cai, X. Mu, N. Lou, and X. Wang, J. Phys. Chem. A 105, 10800-10806 (2001).

${ }^{27}$ B. Zhang, Y. Cai, X. Mu, N. Lou, and X. Wang, J. Chem. Phys. 117, 37013710 (2002).

${ }^{28}$ See supplementary material at http://dx.doi.org/10.1063/1.4817327 for the description of the mass-selected ion mobility system (Figure S1), arrival time distributions (ATDs) for the reactant and product ions to verify the attainment of equilibrium (Figures S2-S5), and ATDs at different drift voltages for ion mobility measurements (Figure S6).

${ }^{29}$ M. J. Frisch, G. W. Trucks, H. B. Schlegel et al., GAussian 09, Revision A.1, Gaussian, Inc., Wallingford, CT, 2009.

${ }^{30}$ M. F. Mesleh, J. M. Hunter, A. A. Shvartsburg, G. C. Schatz, and M. F. Jarrold, J. Phys. Chem. 100, 16082-16086 (1996).

${ }^{31}$ NIST Chemistry WebBook, NIST Standard Reference Database Number 69 , edited by P. J. Linstrom and W. G. Mallard (National Institute of Standards and Technology, Gaithersburg, 2013), also see http://webbook.nist.gov.

${ }^{32}$ E. A. Mason and E. W. McDaniel, Transport Properties of Ions in Gases (John Wiley \& Sons, New York, 1988). 